
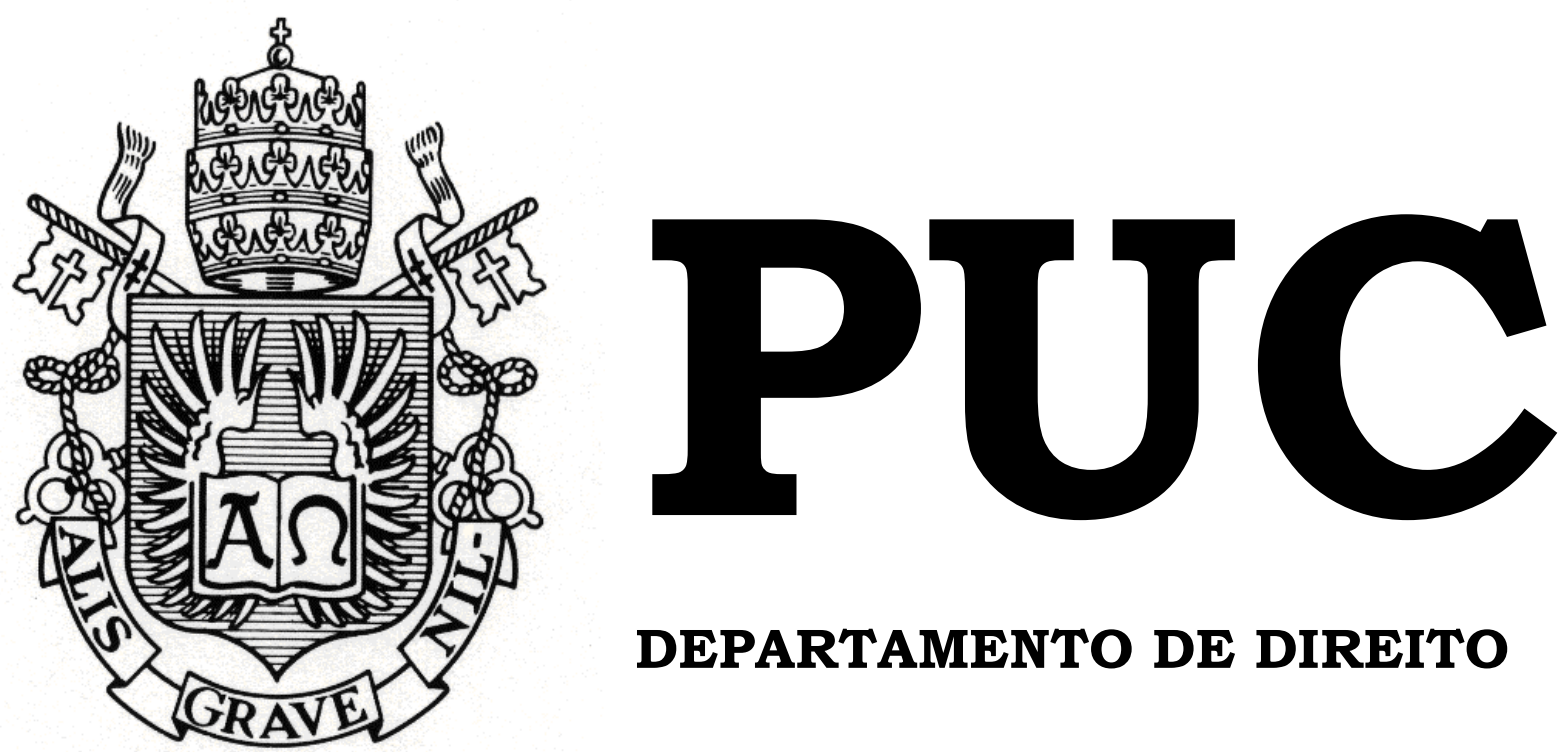

DEPARTAMENTO DE DIREITO

\title{
CONTRATAÇÃO DIRETA PELA ADMINISTRAÇÃO PÚBLICA: \\ PRINCIPAIS ASPECTOS \\ Por
}

Marina Nogueira Pinto

ORIENTADOR: Manoel Messias Peixinho CO-ORIENTADOR: Bruno Garcia Redondo

2016.2

PONTIFÍCIA UNIVERSIDADE CATÓLICA DO RIO DE JANEIRO

RUA MARQUÊS DE SÃO VICENTE, 225 - CEP 22451-900

RIO DE JANEIRO - BRASIL 


\title{
CONTRATAÇÃO DIRETA PELA ADMINISTRAÇÃO PÚBLICA: PRINCIPAIS ASPECTOS
}

\author{
por
}

\section{Marina Nogueira Pinto}

\author{
Monografia apresentada ao \\ Departamento de Direito da \\ Pontifícia Universidade Católica do \\ Rio de Janeiro (PUC-Rio) para a \\ obtenção do Título de Bacharel em \\ Direito.
}

ORIENTADOR: Manoel Messias Peixinho CO-ORIENTADOR: Bruno Garcia Redondo 


\section{DEDICATÓRIA}

À Deus, sem Ele nada seria. À minha mãe, Dayse C. Nogueira e ao meu pai, Ely da S. Pinto, as pessoas mais importantes da minha vida, que influenciaram toda a minha formação e que me apoiam em cada passo. 


\section{AGRADECIMENTOS}

Agradeço à Deus pelas oportunidades colocadas no percorrer do meu caminho, pelos anseios e sonhos que Ele preenche o meu coração e pela energia que ele insere no meu corpo.

Sou grata aos meus pais, Dayse C. Nogueira e Ely S. Pinto por me fornecerem tudo o que julgam ser melhor para a minha formação como pessoa e como profissional e pelo amor incondicional que têm por mim.

Agradeço a minha família, em especial minhas primas, Gabriele e Claudia C. Moscon que me incentivam no dia a dia. As minhas avós Jane Couri e Marly Pinto; e a minha tia Denise C. Moscon que me dão força e coragem sempre.

Agradeço ao meu namorado Bruno Schiavo e a minha amiga Heloísa Schiavo que de forma carinhosa me incentivam.

Por fim, sou grata aos Professores que passaram pela minha jornada na faculdade, em especial ao Manoel Messias Peixinho e ao Bruno Garcia Redondo. 


\section{RESUMO}

A presente monografia pretende simplificar a licitação, procedimento vinculado previsto na Carta Magna, e a contratação direta, perpassando por uma breve análise principiológica, dado que para o instituto em análise ter efetividade tem de estar atrelado à moralidade, à ética e aos bons costumes. Atenta-se que havendo abstinência destes, configura-se o abuso e o desvio de poder. É com a elaboração de correlações e associações que se evidencia a essencialidade da licitação para o interesse público e como se procedem as exceções ao dever de licitar. O propósito deste trabalho científico é explorar individualmente o rol apresentado na lei 8.666/1993 acerca das hipóteses das exceções ao dever de licitar de modo que cumpra os interesses sociais em prol da conveniência pública.

Palavras-Chave: Licitação - Procedimento - Contratação - Ética Competitividade - Vantajosidade - Dispensa - Inexigibilidade - Interesse Público. 


\section{SUMÁRIO}

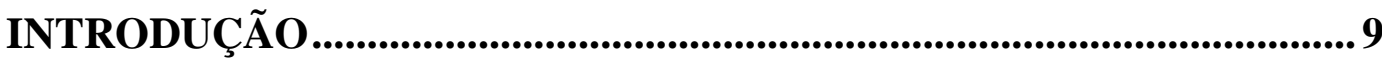

CAPÍTULO 1: LICITAÇÃO E CONTRATOS ADMINISTRATIVOS... 11

1.1. Conceito de Licitação ...................................................................... 11

1.2. Licitação em relação aos comandos constitucionais: .......................... 16

1.2.1. Art. 22 XXVII CF conforme in supra: ......................................16

1.2.2. Art. 37 XXI CF estabelecendo conforme abaixo:.....................19

1.2.3. Art. $173 \S 1^{\circ}$ abaixo transcrito:.................................................. 19

1.2.4. Art. $175 \mathrm{CF}$ conforme in supra: .............................................21

1.3. Objetos e objetivos da licitação: ..........................................................21

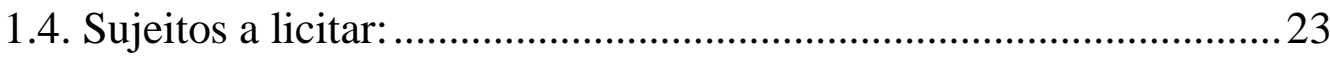

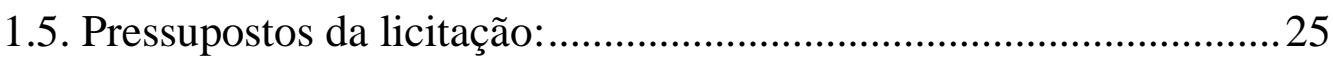

1.6. Breve análise das modalidades de licitação:.......................................26

1.6.1. Concorrência .............................................................................27

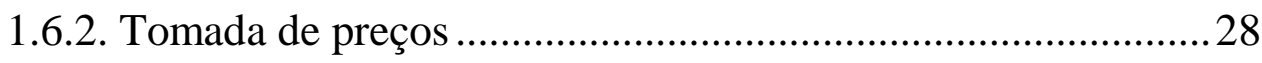

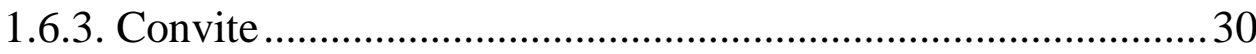

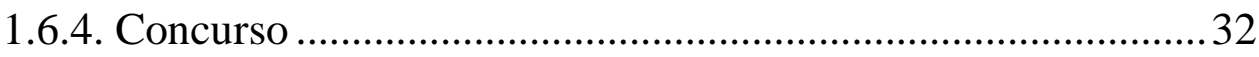

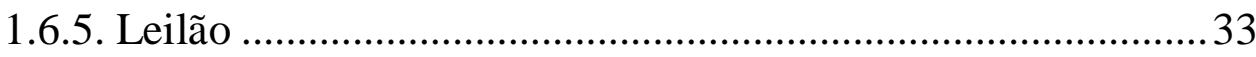

CAPÍTULO 2: PRINCÍPIOS E REGRAS DA CONTRATAÇÃO

DIRETA E INDIRETA................................................................................

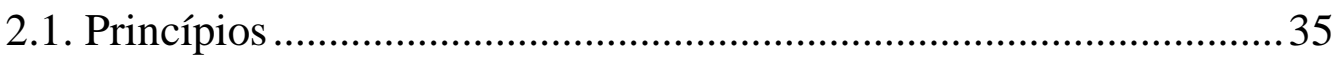

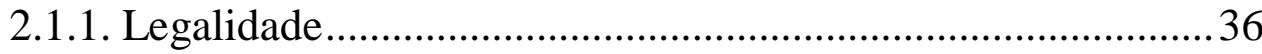

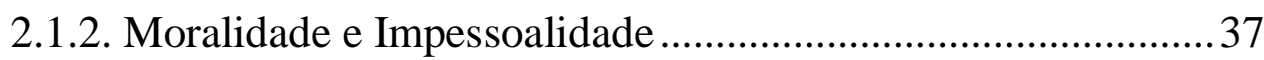

2.1.3. Igualdade entre os licitantes .......................................................39

2.1.4. Publicidade de seus atos e sigilo .................................................40

2.1.5. Probidade Administrativa ........................................................ 41

2.1.6. Vinculação ao instrumento convocatório...................................42

2.1.7. Julgamento objetivo (objetividade decisória) ...........................44

2.1.8. Adjudicação compulsória: ..........................................................45

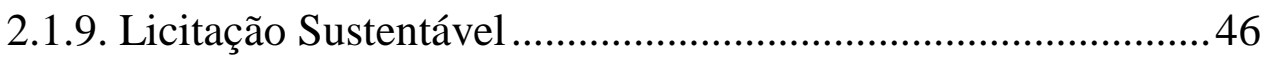




\section{CAPÍTULO 3: CONTRATAÇÃO DIRETA: LICITAÇÃO}

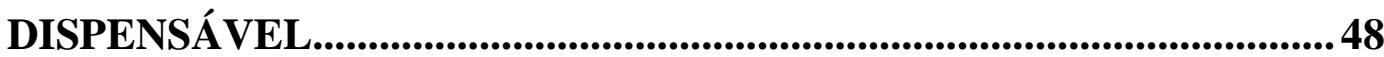

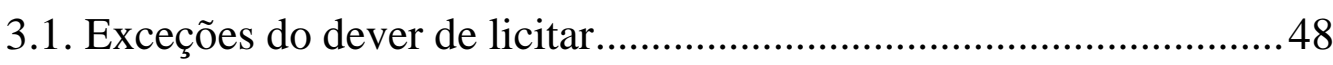

3.2. dispensa de licitação ...........................................................................49

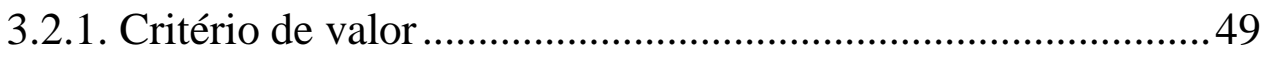

3.2.2. Situações excepcionais ............................................................51

3.2.3. Intervenção no domínio econômico .............................................55

3.2.4. Critério de gêneros perecíveis e obras de arte...........................55

3.2.5. Negócios internacionais............................................................56

3.2.6. Desinteresse na contratação.....................................................56

3.2.7. Entidades sem fins lucrativos ..................................................5

3.2.8. Complementação do objeto .........................................................60

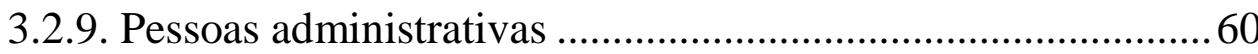

3.2.10. Locação e compra de imóvel....................................................62

3.2.11. Pesquisa e desenvolvimento .................................................... 62

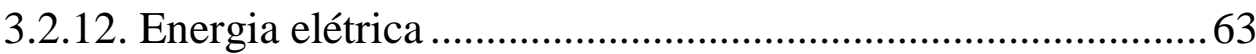

3.2.13. Transferência de tecnologia...................................................63

3.2.14. Consórcios públicos e convênios de cooperação ....................65

3.2.15. Navios, embarcações .................................................................66

3.2.16. Peças no período de garantia técnica.......................................66

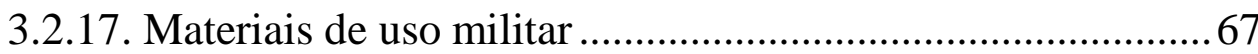

3.2.18. Catadores de materiais recicláveis ..........................................67

3.2.19. Agricultura familiar e reforma agrária .....................................68

3.2.20. Produtos estratégicos para o SUS...............................................69

3.2.21. Programa de cisternas e acesso à água .....................................69

CAPÍTULO 4: CONTRATAÇÃO DIRETA: INEXIGIBILIDADE E LICITAÇÃO DISPENSADA ................................................................72

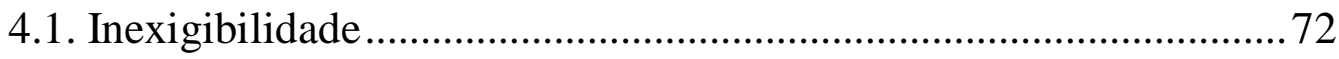

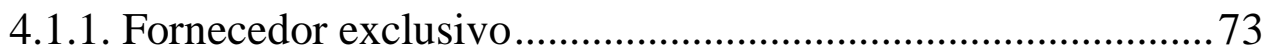

4.1.2. Serviços técnicos especializados ............................................. 74

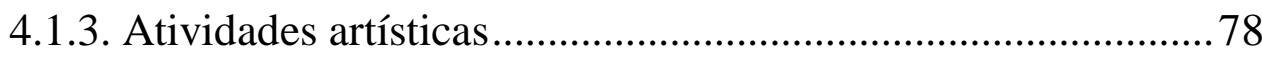


4.2. Licitação Dispensada............................................................. 81

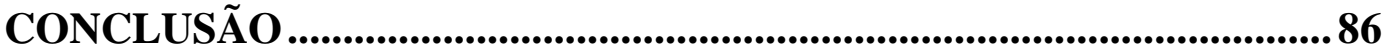

REFERÊNCIAS BIBLIOGRÁFICAS....................................................... 88 


\title{
PRINCIPAIS ABREVIAÇÕES
}

\author{
ADI - Ação Direta de Inconstitucionalidade \\ AGU - Advocacia Geral da União \\ CF - Constituição Federal \\ DF - Distrito Federal \\ EM - Emenda
}

FIOCRUZ - Fundação Oswaldo Cruz

FUNAI - Fundação Nacional do Índio

IBGE - Instituto Brasileiro de Geografia e Estatística

INCRA - Instituto Nacional de Colonização e Reforma Agrária

OS - Organização Social

OSCIP - Organização da Sociedade Civil de Interesse Público

PGE - Procuradoria Geral do Estado

RDC - Regime Diferenciado de Contratação

SENAC - Serviço Nacional de Aprendizagem Comercial

SENAI - Serviço Nacional de Aprendizagem Industrial

STF - Supremo Tribunal Federal

STJ - Superior Tribunal de Justiça

SUS - Sistema Único de Saúde

TCU - Tribunal de Contas da União

UnB - Universidade de Brasília 


\section{INTRODUÇÃO}

A presente monografia tem como objetivo formalizar uma análise global da Lei Federal 8.666/1993 e expor as características da licitação nos seus aspectos gerais, dispondo o conceito, como é remetida na Constituição Federal, objetos e objetivos, sujeitos, pressupostos, modalidades, princípios, percorrendo, então, no tratamento do seu propósito: a contratação direta.

Isto posto, ao se tratar de compras, alienações, concessões, permissões, publicidade e locações realizadas pelo Estado verifica-se o certame ideal para o mesmo a fim de suceder benefícios para a coletividade em favor do interesse público. Ao empreender um diagnóstico anterior à Lei 8.666/1993, anos pretéritos ao de 1993, nota-se que as construções realizadas pelo Estado prejudicavam os cofres públicos, diferente do que se afere com o seu advento, passam, assim, a ser mais coerentes os gastos realizados pela Administração Pública.

Destarte, a partir da necessidade prévia da competição a fim de selecionar a proposta mais vantajosa na contratação de terceiros com a Administração Pública é que ocorre a licitação. Todavia, por que razão a regra é o cumprimento da licitação?

Esse procedimento tem a prerrogativa de amenizar os gastos do Poder Público, servindo como regulador de mercado, visa reduzir o impacto de crises econômicas em benefício do interesse público, já que a partir da competição pautado no princípio da isonomia que haverá a escolha da proposta mais vantajosa para a Administração Pública.

Compreende-se que é no cenário da impossibilidade de competição advindo da previsão legal (licitação dispensada), da inviabilidade de competição (inexigibilidade) ou da escolha discricionária em realizar ou não a licitação (licitação dispensável) que a Administração se depara com a não efetivação do procedimento licitatório. Fenômeno que deve haver a máxima cautela, já que a contratação direta de má-fé pode repercutir 
abusos, fraudes, condutas pessoais, resultando no desfalecimento da Administração Pública e do interesse da coletividade.

No entanto, são as hipóteses de não competição que o presente trabalho está pautado. Nesse diapasão, esse fenômeno reflete a importância da presença e aplicação transparente dos princípios. É no segundo capítulo que alguns deles são examinados evidenciando sua importância em prol da Administração Pública e dos interesses sociais.

Em síntese, as análises aqui implementadas pretendem assingelar a licitação e a contratação direta, de forma que engrandece os princípios norteadores na aplicação do tema e a sua seriedade no que se refere à coletividade, aos interesses sociais, ao desenvolvimento Estatal, à aplicação de políticas sociais e ao oferecimento de serviços públicos. Nesse contexto, é com base nas regras, nos bons costumes, na moralidade e na eticidade que resultará uma licitação eficiente ou uma contratação direta eficaz, baseados no princípio da ética, propulsor de todo o funcionamento da Administração Pública.

Neste cenário, intenta-se a relevância do presente tema. Busca-se, assim, descomplexificar esta apresentação frente ao momento atual, manifesto de crises econômicas constatando os procedimentos viáveis que possibilitam a atenuação dos efeitos da corrente instabilidade financeira. 


\section{CAPÍTULO 1: LICITAÇÃO E CONTRATOS ADMINISTRATIVOS}

\subsection{Conceito de Licitação}

Previamente à contratação com a Administração Pública ${ }^{1}$, desenrola-se um procedimento que tem por finalidade a escolha da proposta mais vantajosa para o ente estatal em situação de negociações: a licitação. Este procedimento precede o contrato e possibilita que qualquer sujeito que preencha os requisitos previstos em lei possa contratar com a Administração Pública. É um meio formal obrigatório disposto no art. 37 XXI da Carta Magna. Esse dispositivo constitucional foi regulamentado pela lei federal 8.666/1993 que será objeto de análise no presente trabalho.

No Brasil atuam predominantemente dois perfis de empresas quanto à consumação de suas atividades: aquelas que as efetuam independentemente do Estado, seja na realização de suas incumbências, na obtenção de verbas; e aquelas que as performances e serviços estatais, vinculados e subordinados à atuação do Estado, submetem-se à regulação administrativa. Desta forma, as primeiras são as atividades privadas e as segundas são as públicas, ou também denominadas estatais ${ }^{2}$.

Convém ressaltar o sentido do termo "estado" que pode ser analisado sob diversos aspectos. Sua origem advém do latim "status" e tem o conceito de “estar firme” (Dallari, 2013, 59). O significado neste trabalho científico é o de um Estado ente personalizado capaz de realizar atividades e responder por elas.

\footnotetext{
1 "A administração Pública é, em sentido material, o conjunto de decisões e operações mediante as quais o Estado e outras entidades públicas procuram, dentro das orientações gerais traçados pela Política e diretamente e mediante estímulo, coordenação e orientação das atividades privadas assegurar a satisfação regular das necessidades coletivas de segurança e de bem-estar dos indivíduos, obtendo e empregando racionalmente para esse efeito os recursos adequados". (Caetano, 1984, p. 5)

${ }^{2} \mathrm{O}$ Estado é essencial para a Sociedade: “... o papel do Estado como instrumento fundamental para a Sociedade, uma missão que continua a ser desempenhada, embora tendo perdido a sua prístina essência unitária em contínuos desdobramentos e abotoamentos de entes e de órgãos, senão que ganhando um a dimensão pluralista, enriquecida pela progressiva complexidade das relações sociais entre os dois autores". (Moreira Neto, 2008, p. 20)
} 
O cenário vigente é de um "Estado de Direito", tendo em vista que o próprio Estado está submisso ao direito aplicado à sociedade ${ }^{3}$.

Como se observa, a contratação de terceiros implementada pelas empresas privadas é diferente de quando transacionado pela Administração Pública, em razão de serem mecanismos discrepantes. É perceptível a prodigalidade da iniciativa privada na contratação com terceiros pautada na autonomia e na liberalidade de contratar ${ }^{4}$. Já a Administração Pública, constituída por entes que exercem atividades complexas em busca do interesse público deve realizar uma espécie de contratação vinculada, submetida ao fenômeno formal da licitação.

Desta maneira, é indubitável que a licitação, procedimento vinculado e preliminar à contratação, é constituída por uma sequência de $\operatorname{atos}^{5}$ formalizados. José dos Santos Carvalho Filho (2016, p. 246 e Santos, 2012, p. 512) descreve a sua natureza jurídica sendo um "...procedimento administrativo com fim seletivo..."

Maria Sylvia Zanella Di Pietro (2014, p. 374) ao tratar do princípio da autonomia da vontade relacionado ao direito privado e ao direito público concebe:

No direito privado, em que vigora o princípio da autonomia da vontade, o contrato celebra-se mediante a apresentação de uma oferta que o outro aceita. No Direito Administrativo, a licitação equivale a uma oferta dirigida a toda a coletividade de pessoas que preencham os requisitos legais e regulamentares constantes do edital; dentre estas, algumas apresentarão suas propostas, que equivalerão a uma aceitação da oferta de condições por parte da Administração; a esta cabe escolher a que seja mais conveniente para resguardar o interesse público, dentro dos requisitos fixados no ato convocatório.

\footnotetext{
3 Atualmente, vive-se em um Estado de Direito Democrático, sendo a base de um Estado Democrático: “... a noção de governo do povo, revelada pela própria etimologia do termo democracia, devendo-se estudar, portanto, como se chegou à supremacia da preferência pelo governo popular e quais instituições do Estado geradas pela afirmação desse governo". (Dallari, 2013, p. 145)

${ }^{4}$ Não é despiciendo destacar importante preleção de Marcelo Caetano (1984, p. 64) : "Por outro lado, o alargamento do âmbito de ação da Administração Pública tem feito com que ela revista formas cada vez mais diversas, de tal modo que a par dos processos de Direito Público (os serviços administrativos tradicionais) usa com frequência crescente de processos de Direito Privado (as sociedades de economia mista ou as sociedades anônimas em que o único acionista é o Estado) e até processos em que o Direito Público e o Direito Privado se entrelaçam (organização corporativa, certas empresas públicas)”.

${ }^{5}$ Leciona Marcelo Caetano (1996, p. 189-190) que: "e convém sublinhar que o ato administrativo não pode consentir todas as classes ou espécies do ato jurídico - porque ele próprio é apenas uma dessas espécies". Observa-se que o "ato administrativo" é uma espécie do gênero "ato jurídico".
} 
A ausência do princípio da autonomia da vontade é evidente na relação pública ${ }^{6}$. Nesta está presente o princípio do procedimento formal em que “... impõe a vinculação da licitação às prescrições legais que a regem em todos seus atos e fases. Essas prescrições decorrem não só da lei mas, também, do regulamento, do caderno de obrigações e até do próprio edital ou convite, que complementa as normas superiores tendo em vista a licitação a que se refere (lei 8.666/1993, art. $4^{\circ}$ )" (Meirelles, 2016, p. 314).

Hely Lopes Meirelles (2016, p. 310) conceitua a licitação como um procedimento relacionado à vantajosidade da seguinte forma:

Licitação é o procedimento administrativo mediante o qual a Administração Pública seleciona a proposta mais vantajosa para o contato de seu interesse, inclusive o da promoção do desenvolvimento econômico sustentável e fortalecimento das cadeias produtivas de bens e serviços domésticos. Como procedimento, desenvolve-se através de uma sucessão ordenada de atos vinculantes para a Administração e para os licitantes, o que propicia igual oportunidade a todos os interessados e atua como fator de eficiência e moralidade nos negócios administrativos. Tem como pressuposto a competição.

Consoante o autor em questão, a descrição de "licitação" se fundamenta por ser um procedimento administrativo implementado pela Administração Pública, sendo um de seus principais fins a vantajosidade. Devem estar presentes outros princípios essenciais como o da igualdade de oportunidade, o da eficiência e o da moralidade. Sobressai-se a diferenciação de "processo" e de "procedimento" elaborada pelo autor que propositalmente discerne ser o "procedimento" a elucidação mais adequada de licitação. Inclui ser "uma sucessão ordenada de atos vinculantes" sendo inviável sua consideração como um processo que, para ele, ostenta um conceito global e mais abrangente. Maria Sylvia Zanella Di Pietro (2014, p. 373) conceitua diferente, assim, o faz seguinte forma:

\footnotetext{
6 "A vontade (o querer administrativo) é simples complemento de um interesse público prévio (contido em lei). A liberdade está calcada nesse simples querer administrativo. Obtempera-se a liberdade a fim de se evitar o arbítrio. A conferência de máxima liberdade ao poder público, na forma como concedida ao particular, sem vinculação prévia a mínimos elementos contidos em lei, proporciona ampla discricionariedade que, nem sempre, coincide com o interesse público". (Souza, 2012, p. 197).
} 
A licitação é um procedimento integrado por atos e fatos da Administração e atos e fatos do licitante, todos contribuindo para formar a vontade contratual. Por parte da Administração, o edital ou convite, o recebimento das propostas, a habilitação, a classificação, a adjudicação, além de outros atos intermediários ou posteriores, como o julgamento de recursos interpostos pelos interessados, a revogação, a anulação, os projetos, as publicações, anúncios, atas etc. Por parte do particular, a retirada do edital, a proposta, a desistência, a prestação de garantia, a apresentação de recursos, as impugnações.

De acordo com a presente definição, a licitação não é constituída apenas por "atos" segundo a definição de Hely Lopes Meirelles. No entanto, para Maria Sylvia Zanella Di Pietro esse procedimento é composto por atos e por fatos tanto da Administração como do licitante. Ela afirma que a licitação está atrelada à vontade contratual e igualmente ao autor citado anteriormente, ela também define a licitação como um "procedimento".

Para Celso Antônio Bandeira de Mello (2012, p.532) a licitação é um certame relacionado à vantajosidade na seguinte forma:

Licitação - em suma síntese - é um certame que as entidades governamentais devem promover e no qual abrem disputa entres os interessados em com elas travar determinadas relações de conteúdo patrimonial, para escolher a proposta mais vantajosa às conveniências públicas. Estriba-se na ideia de competição, a ser travada isonomicamente entre os que preencham os atributos e aptidões necessárias ao bom cumprimento das obrigações que se propõe assumir.

Repara-se que ele não vincula a licitação nem ao processo nem ao procedimento, mas sim a um "certame". Realça a competitividade e a isonomia para se alcançar um dos objetivos base da licitação: a vantajosidade.

Já para José dos Santos Carvalho Filho (2016, p. 246) a licitação:

... o procedimento administrativo vinculado por meio do qual os entes da Administração Pública e aqueles por ela controlados selecionam a melhor proposta entre as oferecidas pelos vários interessados, com dois objetivos - a celebração de contrato, ou a obtenção do melhor trabalho técnico, artístico ou científico.

Constata-se que o autor esclarece a licitação como "procedimento vinculado", contrário aos demais, pois ele relaciona a característica da vinculação ao procedimento e não aos atos como faz Hely Lopes Meirelles. Todavia se 
aproxima deste quando destaca que o objetivo essencial da licitação é a vantajosidade.

Na visão de Marçal Justen Filho (2012, p.441) consoante a licitação:

A licitação é um procedimento administrativo disciplinado por lei e por um ato administrativo prévio, que determina critérios objetivos visando à seleção da proposta de contratação mais vantajosa e à promoção do desenvolvimento nacional sustentável, com observância do princípio da isonomia, conduzido por um órgão dotado de competência específica.

O autor elucida a licitação como "procedimento", indo em convergência com as definições do Hely Lopes Meirelles e José dos Santos Carvalho Filho, conforme exposto acima. Vai ao encontro desses dois autores a definição de um dos principais objetivos da licitação: a vantajosidade. Além de evidenciar esta, salienta-se como outro objetivo essencial da licitação "o desenvolvimento nacional sustentável”. Desse modo, para ele, deve-se relacionar a preservação ambiental ao procedimento licitatório. Sublinha-se que Maria Silvia Zanella Di Pietro sucede na mesma consideração, no entanto o faz na parte principiológica.

Ele aponta o princípio da legalidade, diferindo dos autores anteriores quando afirma ser esse procedimento "disciplinado por lei" e se aproxima do Hely Lopes Meirelles e da Maria Silvia Zanella Di Pietro quando acrescenta ser também disciplinado por ato administrativo.

Marcos Juruena Villela Souto (1998, p.28), por sua vez, através de várias definições de "licitação", elabora a sua própria através de três tópicos. O primeiro ele trata de selecionar propostas atrelando-se à publicidade e igualdade entre os licitantes. $\mathrm{O}$ segundo o autor menciona ser a licitação um processo que destaca o mérito, sendo o vencedor aquele que oferecer a oferta mais vantajosa em prol do interesse público. Por fim, a licitação é um processo e, que objetiva atender a eficiência do administrador que sempre deve agir em prol do interesse público.

Nesse seguimento, para Marcos Juruena Villela Souto, a licitação é um "processo" (Moreira Neto, 2014, p. 197), não diferenciando-o de "procedimento", divergindo de Hely Lopes Meirelles, José dos Santos Carvalho 
Filho e Marçal Justen Filho. Alega ser um "processo de seleção". Aproxima-se destes três autores ao destacar a vantajosidade como objetivo a ser alcançado pela Administração Pública. Acentua-se que deve haver a escolha da proposta mais eficiente que alcance de forma adequada a principal finalidade da Administração: o interesse Público.

Em síntese, o conceito sustentáculo de licitação não apresenta divergência significativa, caracterizando uma linha harmônica de seus apontamentos essenciais a fim de selecionar a proposta mais vantajosa. Não é um procedimento instantâneo, carecendo do preenchimento de determinados requisitos que se submetem a uma sequência de atos. Nesse sentido é um procedimento administrativo instrumental por atuar como instrumento necessário para a contratação pública (Oliveira, 2015, p. 25).

\subsection{Licitação em relação aos comandos constitucionais:}

A licitação como instrumento de regulação do mercado $^{7}$ é uma previsão constitucional regulada em importantes momentos no decorrer da Carta Magna. Além de favorecer à coletividade como um todo, é um procedimento em prol do Poder Público, razão pela qual está disposta na Constituição de 1988. São quatro os dispositivos constitucionais essenciais atrelados à licitação (Meirelles, 2016, p. 307-308):

\subsubsection{Art.22 XXVII CF conforme in supra:}

Art. 22. Compete privativamente à União legislar sobre:

XXVII - normas gerais de licitação e contratação, em todas as modalidades, para as administrações públicas diretas, autárquicas e fundacionais da União, Estados, Distrito Federal e Municípios, obedecido o disposto no art. 37, XXI, e para as empresas públicas

\footnotetext{
${ }^{7}$ Alexandre de Aragão (2013, p. 345-347) demostra funções extraeconômicas da licitação: “... a licitação visa não apenas a proposta mais vantajosa do ponto de vista estritamente econômico de determinada contratação, como também o desenvolvimento nacional sustentável ...". Além deste, ele acrescenta outros, como: princípio da livre concorrência discutida pela Ação Popular n. 2006.34.00.035825-0 e em Suspensão Liminar n.176 no STF e a criação de benefícios ou preferências para certos grupos sociais nos moldes dos princípios da proporcionalidade e igualdade.
} 
e sociedades de economia mista, nos termos do art. 173, § $1^{\circ}$, III; (Redação dada pela Emenda Constitucional n ${ }^{\circ}$ 19, de 1998)

Dispositivo redigido pela EM $\mathrm{n}^{\circ} 19$, trata-se de uma fonte material, incumbindo à União a elaboração de normas gerais de licitação e contratação e todas as suas modalidades. Constata-se que é manifesta a viabilidade de gênese de outras leis que não sejam as de "normas gerais". Rafael Oliveira (2015, p. 27) frisa a dificuldade em definir estas últimas, já que o termo aborda um conceito jurídico indeterminado. Em sua concepção estas normas apresentam qualidade de abstração que garantem que a licitação seja homogênea em todas as esferas federadas, sem que interfiram nas demais regiões (Santos, 2012, p. 513; Figueiredo, 2008, p. 475; Garcia, 2010, p. 03 e Knoplock, 2015, p. 389-390).

Cabe analisar uma peculiar decisão do STF abaixo transcrito:

A CF outorga à União a competência para editar normas gerais sobre licitação (art. 22, XXVII) e permite, portanto, que Estados e Municípios legislem para complementar as normas gerais e adaptá-las às suas realidades. As normas locais sobre licitação devem observar. O art. 37, XXI da CF, assegurando 'a igualdade de condições de todos os concorrentes'. Dentro da permissão constitucional para legislar sobre normas específicas em matéria de licitação, é de se louvar a iniciativa do município de Brumadinho-MG de tratar, em sua lei orgânica, de tema dos mais relevantes em nossa pólis, que é a moralidade administrativa, princípio-guia de toda a atividade estatal, nos termos do art. 37, caput da CF. A proibição de contratação com o Município dos parentes, afins ou consanguíneos, do prefeito, do vice-prefeito, dos vereadores e dos ocupante de cargo em comissão ou função de confiança, bem como dos servidores e empregados públicos municipais, até seis meses após o fim do exercício das respectivas funções, é norma que evidentemente homenageia os princípios da impessoalidade e da moralidade administrativa, prevenindo eventuais lesões ao interesse público e ao patrimônio do Município, sem restringir a competição entre os licitantes. Inexistência de ofensa ao princípio da legalidade ou de invasão da competência da União para legislar sobre normas gerais de licitação (RE 423560, REL. Min. Joaquim Barbosa, 29.5.12 $2^{\mathrm{a}} \mathrm{T}$. (Info 668)).

Neste caso, o STF permitiu a edição de complementação de normas gerais da licitação. Ele considerou inexistente a ofensa ao princípio da legalidade o Município legislar sobre normas gerais de licitação, devendo haver uma análise do caso concreto. Entendimento esse peculiar, já que, regra geral cabe à União legislar sobre normas gerais. 
Deve-se ponderar que normas dispostas na lei 8.666/1993 que disponham sobre leis específicas são válidas no âmbito da União apenas. Para os demais entes são válidas as normas gerais.

No âmbito federal há duas leis gerais de licitação: lei 8.666/1993 e 10.520/2002 e leis que tratam sobre os contratos administrativos ${ }^{8}$ : lei 8.987/1995 e lei 11.079/2004. Além dessas há a lei do RDC - regime diferenciado de contratação prevista na lei 12.462/2011. O objetivo desse preceito confere em fornecer maior celeridade aos procedimentos licitatórios prévios às contratações administrativas presentes no rol do art. $1^{\circ}$ da lei $12.462 / 2011^{9}$.

Essa lei busca munir os aspectos de eficiência, economicidade e realidade para que haja resultados céleres e efetivos (Moreira Neto, 2014, p. 204). No entanto, o presente trabalho científico se limita à lei 8.666/1993. Esta tem um caráter híbrido, já que de um lado é uma lei nacional, pelas normas gerais e por outro é uma lei federal no que se refere às leis específicas (Oliveira, 2015, p. 28). Regra geral, é competência concorrente, isto é, exercida simultaneamente sobre a mesma matéria por diversas autoridades ou órgãos, no caso é da União elaborar normas gerais (nacionais), aplicáveis a todos os Entes Federados; e é

\footnotetext{
8 “... no contrato administrativo a regra da interdependência dos interesses das partes, característica do contrato. $\mathrm{O}$ interesse que a Administração possui de realizar o interesse público ficou ligado ao interesse do particular contraente; e quando, por imperativo das necessidades coletivas, tenha de alterar-se o pactuado de forma a aumentar os encargos do particular, há que remunerá-lo ou indenizá-lo equitativamente, isto é, que atender ao interesse privado" (Caetano, 1996, p. 185)

9 Art. 1o É instituído o Regime Diferenciado de Contratações Públicas (RDC), aplicável exclusivamente às licitações e contratos necessários à realização:

I - dos Jogos Olímpicos e Paraolímpicos de 2016, constantes da Carteira de Projetos Olímpicos a ser definida pela Autoridade Pública Olímpica (APO); e

II - da Copa das Confederações da Federação Internacional de Futebol Associação - Fifa 2013 e da Copa do Mundo Fifa 2014, definidos pelo Grupo Executivo - Gecopa 2014 do Comitê Gestor instituído para definir, aprovar e supervisionar as ações previstas no Plano Estratégico das Ações do Governo Brasileiro para a realização da Copa do Mundo Fifa 2014 - CGCOPA 2014, restringindo-se, no caso de obras públicas, às constantes da matriz de responsabilidades celebrada entre a União, Estados, Distrito Federal e Municípios;

III - de obras de infraestrutura e de contratação de serviços para os aeroportos das capitais dos Estados da Federação distantes até $350 \mathrm{~km}$ (trezentos e cinquenta quilômetros) das cidades sedes dos mundiais referidos nos incisos I e II.

IV - das ações integrantes do Programa de Aceleração do Crescimento (PAC).

V - das obras e serviços de engenharia no âmbito do Sistema Único de Saúde - SUS.

VI - das obras e serviços de engenharia para construção, ampliação e reforma e administração de estabelecimentos penais e de unidades de atendimento socioeducativo;

VII - das ações no âmbito da segurança pública;

VIII - das obras e serviços de engenharia, relacionadas a melhorias na mobilidade urbana ou ampliação de infraestrutura logística; e

IX - dos contratos a que se refere o art. 47-A.

$\mathrm{X}$ - das ações em órgãos e entidades dedicados à ciência, à tecnologia e à inovação.
} 
competência da União, DF e Municípios a elaboração de normas específicas (federais, estaduais, distritais e municipais), com a finalidade de atenderem as peculiaridades socioeconômicas, respeitadas as normas gerais (Oliveira, 2015, p. 27).

\subsubsection{Art. 37 XXI CF estabelecendo conforme abaixo:}

Art. 37. A administração pública direta e indireta de qualquer dos Poderes da União, dos Estados, do Distrito Federal e dos Municípios obedecerá aos princípios de legalidade, impessoalidade, moralidade, publicidade e eficiência e, também, ao seguinte: (Redação dada pela Emenda Constitucional no 19, de 1998).

XXI - ressalvados os casos especificados na legislação, as obras, serviços, compras e alienações serão contratados mediante processo de licitação pública que assegure igualdade de condições a todos os concorrentes, com cláusulas que estabeleçam obrigações de pagamento, mantidas as condições efetivas da proposta, nos termos da lei, o qual somente permitirá as exigências de qualificação técnica e econômica indispensáveis à garantia do cumprimento das obrigações. (Regulamento)

Nos termos do presente dispositivo, a União pode editar outras leis como ocorre com a lei 10.520/2002 que dispõe sobre uma notável modalidade de licitação: o pregão. Salienta-se o caráter da obrigatoriedade da licitação, não podendo a Administração dispensar o procedimento licitatório nos casos em que os pressupostos que regulamentam a competição estiverem presentes, trata-se do princípio licitatório (Moreira Neto, 2014, p. 197).

\subsubsection{Art. $173 \S 19 \mathrm{CF}$ abaixo transcrito:}

Art. 173. Ressalvados os casos previstos nesta Constituição, a exploração direta de atividade econômica pelo Estado só será permitida quando necessária aos imperativos da segurança nacional ou a relevante interesse coletivo, conforme definidos em lei.

$\S 1^{\circ}$ A lei estabelecerá o estatuto jurídico da empresa pública, da sociedade de economia mista e de suas subsidiárias que explorem atividade econômica de produção ou comercialização de bens ou de prestação de serviços, dispondo sobre: (Redação dada pela Emenda Constitucional n ${ }^{\circ} 19$, de 1998) 
III - licitação e contratação de obras, serviços, compras e alienações, observados os princípios da administração pública; (Incluído pela Emenda Constitucional $\mathrm{n}^{\circ}$ 19, de 1998)

Observa-se que a administração direta e indireta estão obrigadas a licitar. Até mesmo as empresas estatais, sociedades de economia privada - prestadoras de atividade econômica ou prestadoras de serviços públicos - são submetidas à licitação.

Ocorre que o presente dispositivo permite que seja elaborado um estatuto jurídico específico para as empresas que prestem atividade econômica, possibilitando sua desvinculação com a lei 8666/1993. Entretanto, esse estatuto foi elaborado no ano de 2016. A Lei 13.303/2016 regulamentou o art. 173 CF o qual prevê a possibilidade de editar a lei das estatais. Essa Lei promulgada em 30 de junho de 2016 não teve período de vacatio.

Ela insiste na distinção das empresas estatais em: empresas públicas e sociedades de economia mista. Nesse sentido, as empresas públicas permanecem constituídas integralmente pelo capital estatal, não havendo participação privada; já a sociedade de economia mista continua formada por capital privado e público concomitantemente. Manteve-se também o objeto dessas empresas: prestação de serviço público e exploração de atividade econômica.

Originou-se uma organização setorizada das empresas estatais. A lei regulamentou requisitos de transparência, carta anual, publicidade das atividades que exerce, etc. Deve haver maior transparência, de modo que essas empresas contenham um comitê de auditoria estatutário para reger o controle interno sobre suas atividades e um conselho de administração.

Finalmente, as empresas estatais passaram a se submeter a um procedimento licitatório diferente, previsto no art. 28 dessa nova lei ${ }^{10}$. A licitação segue os moldes das microempresas e empresas de pequeno porte. É expresso na

\footnotetext{
10 Art. 28. Os contratos com terceiros destinados à prestação de serviços às empresas públicas e às sociedades de economia mista, inclusive de engenharia e de publicidade, à aquisição e à locação de bens, à alienação de bens e ativos integrantes do respectivo patrimônio ou à execução de obras a serem integradas a esse patrimônio, bem como à implementação de ônus real sobre tais bens, serão precedidos de licitação nos termos desta Lei, ressalvadas as hipóteses previstas nos arts. 29 e 30.

§ 1o Aplicam-se às licitações das empresas públicas e das sociedades de economia mista as disposições constantes dos arts. 42 a 49 da Lei Complementar no 123, de 14 de dezembro de 2006.
} 
lei que elas devem dar preferência ao pregão quando possível. O rol de dispensa e de inexigibilidade se assemelham com o rol da Lei 8.666/1993.

\subsubsection{Art.175 CF conforme in supra:}

Art. 175. Incumbe ao Poder Público, na forma da lei, diretamente ou sob regime de concessão ou permissão, sempre através de licitação, a prestação de serviços públicos.

Verifica-se que a lei 8666/1993 é a espinha dorsal das normas gerais sobre licitações e contratos administrativos (Meirelles, 2016, p. 309). É pressuposto de validade da licitação a igualdade entre todos os licitantes, já o seu objetivo, que será a seguir o tópico em questão, é a seleção da proposta mais vantajosa para a Administração (Souto, 1998, p. 23).

\subsection{Objetos e objetivos da licitação:}

O objeto da licitação ganha respaldo quando há o preenchimento de todos os requisitos necessários para haver tal procedimento. É precípuo que o objeto seja: lícito, ajustando-se conforme à lei; possível, já que a sua impossibilidade gera a nulidade do ato; e determinado ou determinável.

A licitação é impraticável quando houver um objeto singular ou quando há apenas um ofertante, tendo em vista que além dos requisitos típicos de qualquer negócio jurídico como disposto acima, é essencial que haja o caráter de competição intrínseco ao objeto a fim de que se suceda o procedimento licitatório.

Percebe-se que ao se mencionar a importância dos objetos da licitação, deve-se corroborá-los em uma perspectiva da possibilidade de licitação. Deve haver esse procedimento quando os objetos forem homogêneos, inviabilizando tal formalidade licitatória se os bens forem desiguais (Mello, 2012, p. 552).

Nesse sentido, Celso Antônio Bandeira de Mello acentua que "são licitáveis unicamente objetos que possam ser fornecidos por mais de uma pessoa, 
uma vez que a licitação supõe disputa, concorrência, ao menos potencial, entre ofertantes" (Mello, 2012, p. 551).

Os objetos da licitação estão dispostos no art. $2^{\circ}$ da lei $8666 / 93^{11}$ e suas respectivas definições estão no art. $6^{\text {o }}$ as leis $8.666 / 1993^{12}$. Percebe-se que os objetos são basicamente: obras (conceito abrangente podendo ser desde construção, fabricação, ampliação contando que haja execução direta ou indireta); serviços (atividade que possua utilidade para o ente estatal, diferindo da obra na medida em que não há nenhum tipo de transformação) (Garcia, 2010, p. 07), incluindo a publicidade; compras (aquisição remunerada); alienações (transferência de propriedade); concessões (anuência de determinado ato); permissões (aquiescência); locações (transferir algo por um tempo determinado) (Medauar, 2005, p. 210-211).

Avulta Hely Lopes Meirelles (2016, p. 322) que a "licitação sem caracterização de seu objeto é nula, porque dificulta a apresentação das propostas e compromete a lisura do julgamento e a execução do contrato subsequente". Agrega ainda que o objeto da licitação confunde-se com o do contrato, que pode ser uma obra, um serviço, uma compra, uma concessão, uma alienação... (Meirelles, 2016, p. 325). A presente definição elaborada por ele pode ser analisada a luz do Estatuto:

Art. 40. O edital conterá no preâmbulo o número de ordem em série anual, o nome da repartição interessada e de seu setor, a modalidade, o regime de execução e o tipo da licitação, a menção de que será regida por esta Lei, o local, dia e hora para recebimento da documentação e proposta, bem como para início da abertura dos envelopes, e indicará, obrigatoriamente, o seguinte:

I - objeto da licitação, em descrição sucinta e clara;

\footnotetext{
11 Art. 2o As obras, serviços, inclusive de publicidade, compras, alienações, concessões, permissões e locações da Administração Pública, quando contratadas com terceiros, serão necessariamente precedidas de licitação, ressalvadas as hipóteses previstas nesta Lei.

${ }^{12}$ Art. 6o Para os fins desta Lei, considera-se: I - Obra - toda construção, reforma, fabricação, recuperação ou ampliação, realizada por execução direta ou indireta; II - Serviço - toda atividade destinada a obter determinada utilidade de interesse para a Administração, tais como: demolição, conserto, instalação, montagem, operação, conservação, reparação, adaptação, manutenção, transporte, locação de bens, publicidade, seguro ou trabalhos técnico-profissionais; III - Compra - toda aquisição remunerada de bens para fornecimento de uma só vez ou parceladamente; V - Obras, serviços e compras de grande vulto aquelas cujo valor estimado seja superior a 25 (vinte e cinco) vezes o limite estabelecido na alínea "c" do inciso I do art. 23 desta Lei.
} 
Quanto aos objetivos da licitação, pode-se destacar três primordiais, são eles: a observância do princípio da isonomia; a vantajosidade, em que deve haver a seleção da proposta mais vantajosa para a administração; e a promoção do desenvolvimento nacional sustentável conforme reza o art. $3^{\circ}$, conforme abaixo:

Art. 3o A licitação destina-se a garantir a observância do princípio constitucional da isonomia, a seleção da proposta mais vantajosa para a administração e a promoção do desenvolvimento nacional sustentável e será processada e julgada em estrita conformidade com os princípios básicos da legalidade, da impessoalidade, da moralidade, da igualdade, da publicidade, da probidade administrativa, da vinculação ao instrumento convocatório, do julgamento objetivo e dos que lhes são correlatos

José dos Santos Carvalho Filho (2016, p. 252-253) realça: "O objeto imediato é a seleção de determinada proposta que melhor atenda aos interesses da Administração." e “... o objeto mediato, que consiste na obtenção de certa obra, serviço, compra, alienação, locação ou prestação de serviço público, a serem produzidos por particular por intermédio de contratação formal" (2016, p. 253). Constata-se que a licitação é um meio de a Administração atingir suas finalidades perante terceiros de forma impessoal.

Celso Antônio Bandeira de Mello (2012, p. 534-535) certifica que frente aos objetivos presentes na lei de licitação, há três exigências públicas, são elas:

Proteção aos interesses públicos e recursos governamentais- ao se procurar a oferta mais satisfatória; respeito aos princípios da isonomia e impessoalidade (previstos nos arts. $5^{\circ}$ e 37, caput) - peça abertura de disputa do certame; e finalmente, obediência aos reclamos de probidade administrativa, imposta pelos arts. 37, caput, e 85, V, da Carta Magna Brasileira.

Nesse sentido, o regime jurídico dos contratos administrativos objetiva escolher a proposta com maior vantajosidade, respaldando todos os princípios relacionados ao tema para que seja um objeto primoroso e perdurável no procedimento licitatório.

\subsection{Sujeitos a licitar:}


O item em questão examina quem está condicionado a fazer licitação. Preliminarmente, cabe aludir o art. $1^{\circ}$ da lei $8666 / 93^{13}$ que alinha os sujeitos, são eles: os órgãos da administração direta; os entes da administração indireta (fundações públicas; autarquias; sociedades de economia mista; empresas públicas); o consórcio público previsto na lei 11.107, vale a ressalva que quando constituídos podem ter personalidade pública ou privada; associação cuja natureza é de autarquia; Agência reguladora; as fundações públicas como a FIOCRUZ; IBGE; FUNAI.

Ainda estão sujeitos a realizar a licitação, os entes de personalidade jurídica das fundações: de direito público e de direito privado como as autarquias que exercem atividade típica de estado (regime de direito público); as autarquias profissionais como as autarquias corporativas (conselhos). É válido citar uma exceção: a OAB é considerada entidade "sui generis" e não se sujeita às regras que as demais autarquias se submetem.

Outros sujeitos são as empresas públicas e sociedades de economia mista que desempenham duas atividades: econômica e prestação de serviços públicos. Ao se tratar das empresas estatais, mais especificamente aquelas que exploram atividade econômica, deve-se atentar para o art. $173 \S^{\circ}{ }^{\circ} \mathrm{III}$ CF (Santos, 2012, p. 514) que dispõe sobre a lei específica anteriormente explicada.

Já as entidades controladas direta/indiretamente pela União, Estados, DF e Municípios do terceiro setor (são as entidades paraestatais) que não integram a administração pública como a OS, OSCIP, Sistema S (SENAI, SENAC) não estão sujeitas ao dever de licitar. Deve haver um procedimento similar que respeite os princípios da licitação.

Sintetiza-se que os principais sujeitos a licitar, resumidamente, são: os entes da administração direta e indireta e as demais controladas, direta ou indiretamente, pelo Poder Público, abrangendo entidades que recebam dinheiro

\footnotetext{
13 Art. 1o Esta Lei estabelece normas gerais sobre licitações e contratos administrativos pertinentes a obras, serviços, inclusive de publicidade, compras, alienações e locações no âmbito dos Poderes da União, dos Estados, do Distrito Federal e dos Municípios. Parágrafo único. Subordinam-se ao regime desta Lei, além dos órgãos da administração direta, os fundos especiais, as autarquias, as fundações públicas, as empresas públicas, as sociedades de economia mista e demais entidades controladas direta ou indiretamente pela União, Estados, Distrito Federal e Municípios).
} 
público para gastos com o pessoal, terceiro setor. Matheus Carvalho (2015, p. 437) atenta que:

O Fundo é objeto de direito e não sujeito. Trata-se de um equívoco legislativo uma vez que tais fundos representam normalmente mera destinação de verbas públicas. Excepcionalmente, tais fundos podem ser regulamentados por lei como órgãos integrantes da Administração Direta ou Fundações Públicas de direito público, o que já os colocaria nas hipóteses anteriores.

Dessa forma, dependendo da destinação dos fundos eles são sujeitos a licitar ou não. Vale ainda salientar o que Marcos Juruena Villela Souto (1998, p. 27) expõe:

Em regra, não se vislumbra nos fundos especiais personalidade jurídica, sendo, portanto, inaptos para contraírem direitos e obrigações. Suas contratações e demais despesas são feitas pela Administração Pública que o instituiu, embora a gestão de tais recursos possa ser transferida de um órgão da própria Administração Pública para uma pessoa jurídica, em decorrência do poder descentralizador do estado, podendo a descentralização operar-se tanto para entidade da Administração, como para particular. O importante não é a personalidade do gestor, mas a autonomia da gestão de uma verba específica.

Diante das observações analisadas, o fundo quando considerados "sujeitos" e não "objetos" devem estar dispensados de licitar diante de seu caráter contábil e natureza financeira instituídos por lei. A sua gestão passa a ser de órgãos já existentes na organização de serviços públicos ${ }^{14}$.

\subsection{Pressupostos da licitação:}

Celso Antônio Bandeira de Melo aponta três pressupostos de três ordens que devem estar presentes em qualquer tipo de licitação, havendo desvio de finalidade se ausentes. São eles: o lógico, o jurídico e o fático.

Para ele "é pressuposto lógico da licitação a existência de uma pluralidade de objetos e de uma pluralidade de ofertantes" (Mello, 2012, p. 550).

\footnotetext{
14 Na ADI 1923/DF, Red. P. ac. Min. Luiz Fux, 154.15. Pleno afirma que as OS não se sujeitam à licitação da lei 8666, mas deveriam fazer um procedimento de contratação baseado nos princípios da lei 8666. O procedimento não é da lei de licitação.
} 
Acrescenta que "é pressuposto jurídico o de que, em face do caso concreto, a licitação possa se constituir em meio apto, ao menos em tese, para a Administração acudir ao interesse que deve prover" (Mello, 2012, p. 551). Ele afirma que "com efeito: a licitação não é um fim em si mesmo; é um meio para chegar ultimamente a um dado resultado: o travamento de uma certa relação jurídica" (Mello, 2012, p. 551). Dessa forma, demonstra-se a importância do interesse público na realização do certame.

Por fim, "é pressuposto fático da licitação a existência de interessados em disputa-la. Nos casos em que tal interesse não concorra, não há como realizá-la" (Mello, 2012, p. 551).

Através das análises de pressupostos, conclui-se que o fim precípuo da realização da série de procedimentos formais a partir destes pré-requisitos é o interesse público pertencente à coletividade. Neste há a expectativa do todo, jamais de autoridades por maiores que sejam os poderes (Niebuhr, 2013, p. 31).

Já Odete Medauar (2005, p. 217-218) considera sete conceitos chaves prévios para se compreender a licitação, alguns deles são: que as modalidades mais efetivas presentes na lei 8.666/1993 são a concorrência, a tomada de preço e o convite. São previstos com base no valor do contrato, sendo que quanto maior o valor, maior a complexidade do mesmo. Essas modalidades são efetivadas até a fase de julgamento pela comissão permanente.

\subsection{Breve análise das modalidades de licitação:}

As modalidades são especificidades de condução do procedimento de licitar. A lei 8.666/1993 dispõe de cinco modalidades de licitação: concorrência; tomada de preços; convite; concurso; e leilão. Estas variam a depender do objeto e do seu respectivo valor. Nesse diapasão, há três objetos para cinco modalidade de licitação específica. Isso ocorre porque na concorrência, tomada de preços e convite possuem os mesmos objetos: contratação de obras, serviços e fornecimento. 
Acentua-se que os artigos 22 e 23 da lei 8.666/1993 dispõem sobre as modalidades da licitação, suas definições, características e limitações quanto ao valor. Aponta-se a criação de novas modalidades e a combinação delas são hipóteses vedadas pelo ordenamento. $\mathrm{O}$ presente tópico busca tecer considerações, relacionar de forma sistemática e breve os dispositivos apontados acima e os mencionar doutrinadores que desenvolvem o tema.

Além das modalidades da lei 8.666/1993 há a lei 10.520/2002 que instituiu uma sexta modalidade de licitação denominada "pregão". Há ainda a "consulta", modalidade específica de determinadas agências reguladoras, no entanto, essas duas não estão dispostas na lei de licitações, não sendo, pois, objeto de exploração neste trabalho científico.

Enquanto a concorrência, a tomada de preços e o convite são verificados sob o aspecto do "valor" do contrato, o concurso, o leilão e o pregão são averiguados sob a esfera do "objeto" a ser contratado.

\subsubsection{Concorrência}

É a modalidade para contratações de grande vulto, pode haver a atuação de qualquer interessado, cadastrados ou não, bastando o cumprimento de requisitos conforme o art. In supra:

Art. $22 \S 1^{\circ}$ Lei 8.666/1993 Concorrência é a modalidade de licitação entre quaisquer interessados que, na fase inicial de habilitação preliminar, comprovem possuir os requisitos mínimos de qualificação exigidos no edital para execução de seu objeto.

A concorrência é aplicável em obras e serviços de engenharia acima de $\mathrm{R} \$$ 1.500.000,00 (um milhão e quinhentos mil reais) e para demais compras e serviços o valor deve ser acima de $\mathrm{R} \$ 650.000,00$ (seiscentos e cinquenta mil reais). Na possibilidade de atuação de consórcios públicos, a faixa de valor é o dobro se ele for formado por até três entidades federativas e o triplo se esse número exceder, nos moldes do art. $28 \S 8^{\circ}$ da Lei 8.666/1993.

Acrescenta-se ao objeto dessa espécie de licitação o que expõe o dispositivo conforme na página seguinte: 
Art. 23 § 3o A concorrência é a modalidade de licitação cabível, qualquer que seja o valor de seu objeto, tanto na compra ou alienação de bens imóveis, ressalvado o disposto no art. 19, como nas concessões de direito real de uso e nas licitações internacionais, admitindo-se neste último caso, observados os limites deste artigo, a tomada de preços, quando o órgão ou entidade dispuser de cadastro internacional de fornecedores ou o convite, quando não houver fornecedor do bem ou serviço no País.

No parágrafo em argumento é irrelevante o valor a ser contratado, já que se enfatiza a natureza do contrato. $\mathrm{O} \S 3^{\circ} \mathrm{em}$ balanço refere-se que em caso de compra ou alienação de bens imóveis (exceto o art. 19), havendo concessões de uso real e licitações internacionais, será adotada a concorrência, desconsiderando o valor pactuado. A execução da modalidade em estudo não se restringe à Lei 8.666/1993, sendo aplicável em leis especiais também como na concessão de serviço pública ${ }^{15}$.

Percebe-se que a concorrência possui ampla publicidade, universalidade e elevado formalismo. A publicação deve ser feita com uma antecedência mínima de 30 dias exceto se for uma licitação do tipo "melhor-técnica" ou "técnica e preço" que possuem prazo de 45 dias. O atributo da universalidade consiste na possibilidade de participação de qualquer interessado, já o formalismo se respalda no rigor dos procedimentos essenciais de participação (Garcia, 2010, p. 18-19).

\subsubsection{Tomada de preços}

É a modalidade de maior formalidade após a concorrência, já que esta se destina a contratações de grande vulto e aquela de médio.

Art. $22 \S 2$ o Lei 8.666/1993 Tomada de preços é a modalidade de licitação entre interessados devidamente cadastrados ou que atenderem a todas as condições exigidas para cadastramento até o terceiro dia anterior à data do recebimento das propostas, observada a necessária qualificação.

\footnotetext{
15 Art. 2o Para os fins do disposto nesta Lei, considera-se:

II - concessão de serviço público: a delegação de sua prestação, feita pelo poder concedente, mediante licitação, na modalidade de concorrência, à pessoa jurídica ou consórcio de empresas que demonstre capacidade para seu desempenho, por sua conta e risco e por prazo determinado;
} 
Maria Sylvia Zanella Di Pietro (2014, p. 417) trata da importância do registro cadastral que deve ser mantido pelos órgãos e entidades para maior eficiência e celeridade da licitação, conforme disposto:

O registro cadastral deve ser mantido pelos órgãos e entidades que realizem frequentes licitações, devendo ser atualizados anualmente (art. 34); é facultada, contudo, a utilização de registros cadastrais de outros órgãos ou entidades da Administração Pública (art. 34, $\S 2^{\circ}$ ), o que abrange a Administração Direta e Indireta da União, dos Estados, do Distrito Federal e dos Municípios, inclusive as entidades com personalidade de direito privado sob controle do poder público e das fundações por ele instituídas ou mantidas (art. $\left.6^{\circ}, \mathrm{XI}\right)$.

É cabível a tomada de preços em obras e serviços de engenharia de até $\mathrm{R} \$$ 1.500.000,00 (um milhão e quinhentos mil reais) e para as demais compras e serviços no valor de até $\mathrm{R} \$ 650.000,00$ (seiscentos e cinquenta mil reais).

Infere-se que na tomada de preços os interessados devem ser devidamente cadastrados ou acolher todas as condições exigidas para o cadastramento até o terceiro dia anterior à data de recebimento das propostas. O prazo é de 30 dias para o tipo de licitação de melhor técnica ou técnica e preço e de 15 dias nos demais casos, sendo possível perceber que seu período é menor que o da concorrência.

Em se tratando de licitação internacional, é aplicável esta categoria licitatória quando o valor for compatível e deve ser realizada no momento em que o órgão ou entidade dispuser de cadastro internacional de fornecedores (requisitos cumulativos).

Em relação à participação dos que não são cadastrados, há controvérsia doutrinária. A polêmica consiste no art. $22 \S 2^{\circ}$ da lei 8.666 mais especificamente no seguinte extrato do dispositivo: “... que atenderem a todas as condições exigidas para cadastramento até o terceiro dia anterior à data do recebimento das propostas, observada a necessária qualificação".

Rafael Oliveira (2015, p. 97) diferencia dois entendimentos sobre a controvérsia e se enquadra na segunda corrente conforme abaixo transcrito:

$1^{\circ}$ entendimento: Os interessados devem obter o cadastramento efetivo até o terceiro dia anterior da data do recebimento das propostas. Nesse sentido: Jessé Torres Pereira 
Junior; $2^{\circ}$ entendimento: os interessados devem apresentar todos os documentos exigidos para o cadastro até o terceiro dia anterior da data do recebimento das propostas, mas a decisão relativa ao cadastramento poderá ser proferida após esse prazo. Enquanto não decididos os cadastramentos (as habilitações), os envelopes das propostas não serão abertos. Nesse sentido: Marçal Justen Filho e Marcos Juruena Villela Souto.

É uma característica essencial dessa modalidade a inscrição ou a sua possibilidade nos registros cadastrais. A tomada de preços fica aferida no momento da inscrição dos registros cadastrais. Rafael Oliveira (2015, p. 96) inclui que:

As características básicas do registro cadastral podem ser assim enumeradas: a) deve ser atualizada no mínimo, anualmente, e deverá estar permanentemente aberto aos interessados (art. 34, $\S 1^{\circ}$, da Lei de Licitações); b) é facultado às unidades administrativas utilizarem-se de registros cadastrais de outros órgãos ou entidades da Administração Pública (art. 34, § $2^{\circ}$ ); c) os inscritos serão classificados por categorias, tendo-se em vista sua especialização, subdivididas em grupos, segundo a qualificação técnica e econômica avaliada pelos elementos constantes da documentação relacionados nos arts. 30 e 31 da Lei de Licitações (art. 36); d) os cadastrados receberão certificado de cadastramento (Certificado de Registro Cadastral), renovável sempre que atualizarem o registro $\left(\operatorname{art} .36, \S 1^{\circ}\right)$.

O cadastro é o instrumento para se obter o registro cadastral. É uma habilitação prévia que gera maior facilidade no procedimento licitatório, desburocratizando-o em especial, na fase da habilitação. Foi o cadastramento que proporcionou à Administração agilidade e eficiência dado que o certificado de registro cadastral, documento de validade de 1 ano, antecipa os documentos indispensáveis nesta fase.

Esses registros são essenciais nas cartas- convite e tomadas de preço já que passa a ser uma condição para a realização da licitação (Aragão, 2013, p. 321-322). Outrora esse cadastramento era obrigatório expressamente apenas para a tomada de preços, porém, com tamanha efetividade e celeridade, passou a ser válida e possível para as demais modalidades licitatórias.

\subsubsection{Convite}

Modalidade que apresenta o menor formalismo já que se aplica a contratações de menor vulto. 
Art. 22 § 3o Lei 8.666/1993 Convite é a modalidade de licitação entre interessados do ramo pertinente ao seu objeto, cadastrados ou não, escolhidos e convidados em número mínimo de 3 (três) pela unidade administrativa, a qual afixará, em local apropriado, cópia do instrumento convocatório e o estenderá aos demais cadastrados na correspondente especialidade que manifestarem seu interesse com antecedência de até 24 (vinte e quatro) horas da apresentação das propostas.

Em uma leitura superficial do dispositivo transcrito chega-se à conclusão de que deve convidar no mínimo três interessados para participarem do convite. No entanto, prevalece o entendimento de que o envio desses três convites para a validade do certame não é o bastante, mas a apresentação efetiva de, ao menos, três propostas, fomentando a competição e evitando fraudes. Em situações que seja impossível obter o número mínimo de três licitantes, a Administração deverá justificar para que não seja preciso renovar a licitação. Nessa situação, havendo duas propostas, por exemplo, a Administração selecionará a melhor e formalizará o contrato. Na hipótese de haver apenas um licitante, a Administração efetuará a contratação direta (Oliveira, 2015, p. 99).

Com o intuito de se evitar a violação do princípio da impessoalidade e que sempre sejam escolhidos os mesmos licitantes, há a previsão do parágrafo reproduzido abaixo:

$\S 60$ Na hipótese do $\S 30$ deste artigo, existindo na praça mais de 3 (três) possíveis interessados, a cada novo convite, realizado para objeto idêntico ou assemelhado, é obrigatório o convite a, no mínimo, mais um interessado, enquanto existirem cadastrados não convidados nas últimas licitações.

§ 7o Quando, por limitações do mercado ou manifesto desinteresse dos convidados, for impossível a obtenção do número mínimo de licitantes exigidos no § 3o deste artigo, essas circunstâncias deverão ser devidamente justificadas no processo, sob pena de repetição do convite.

Quanto ao $\S 6^{\circ}$ conclui-se que não é o objetivo da Administração aumentar o número de convidados a cada nova licitação, sendo seu propósito evitar a repetição dos mesmos convidados "ex.: a Administração poderia substituir um dos convidados na licitação anterior por outro particular, sem a necessidade de convidar quatro interessados" (Oliveira, 2015, p. 99). 
Dessa forma, é possível que a licitação prossiga com seus procedimentos mesmo configurado expresso desinteresse dos convidados. Quanto à habilitação, nos moldes do art. $32 \S 1^{\circ}$ da lei 8.666/93, é simplificada. É admitida a dispensa, total ou parcial, dos documentos comprobatórios como a habilitação jurídica, a qualificação técnica, a qualificação econômico-financeira e a regularidade fiscal. (Garcia, 2010, p. 20-21 e Oliveira, 2015, p. 99).

A modalidade de convite é cabível para obras e serviços de engenharia de até $\mathrm{R} \$ 150.000,00$ (cento e cinquenta mil reais) e para as demais compras e serviços até $\mathrm{R} \$ 80.000,00$ (oitenta mil reais).

Percebem-se peculiaridades do instrumento convocatório, algumas delas são: não se exige o edital por haver a carta convite que deverá ser endereçada para os interessados do ramo pertinente ao seu objeto; é composta por cadastrados ou não, escolhidos ou convidados em número mínimo de três pela unidade administrativa; estenderá aos demais cadastrados na correspondente especialidade que manifestarem interesse 24 horas da data da apresentação das propostas.

É preciso cautela para o escorreito entendimento, já que os não cadastrados só participam se forem convidados enquanto os cadastrados que manifestarem interesse em vinte quatro horas de antecedência podem participar. É inegável que essa modalidade perdeu espaço para outras mais céleres como o pregão.

\subsubsection{Concurso}

Modalidade que independe de valor estimado, sendo permitida a participação de qualquer eventual interessado. O Estatuto dispensa no todo ou em parte a apresentação de alguns documentos, conforme o art. $32 \S^{\circ}$ lei 8.666/93. Interessante observação é que ao se tratar de um projeto intelectual, a comissão que dirige a licitação deve ser criteriosa frente ao subjetivismo de seletividade, não podendo ser facilitado desvio de finalidade (Carvalho Filho, 2016, p. 291). 
Art. $22 \S 4^{\circ}$ Lei 8.666/1993 Concurso é a modalidade de licitação entre quaisquer interessados para escolha de trabalho técnico, científico ou artístico, mediante a instituição de prêmios ou remuneração aos vencedores, conforme critérios constantes de edital publicado na imprensa oficial com antecedência mínima de 45 (quarenta e cinco) dias.

Nesse ínterim, é uma modalidade que fornece serviço para a escolha de trabalho técnico, artístico ou científico que por meio da instituição de prêmio ou de remuneração contempla o vencedor. O concurso não utiliza de nenhum dos tipos clássicos da licitação, em síntese: vence aquele que apresentar o melhor trabalho técnico.

\subsubsection{Leilão}

Modalidade para quaisquer interessados tem por escopo a venda de bens móveis inservíveis, a venda de produtos legalmente apreendidos ou penhorados e a alienação de bens imóveis adquiridos em procedimento judicial ou através de dação em pagamento, conforme o art. 19 do estatuto (Carvalho Filho, 2016, p. 292 e Garcia, 2010, p. 22-23). O tipo de licitação "maior lace" predomina, devendo ser igual ou superior ao valor da avaliação. Modelo esse que o princípio da publicidade é atentado na sua forma mais ampla.

Dessa maneira, como no concurso e no convite, o art. $32 \$ 1^{\circ}$ do Estatuto admite a dispensa de determinados documentos atrelados à habilitação dos interessados. Vale ressair que quem executa propriamente dito o leilão é o leiloeiro oficial ou servidor designado pela Administração.

Art. $22 \S 5$ o Lei 8.666/1993 Leilão é a modalidade de licitação entre quaisquer interessados para a venda de bens móveis inservíveis para a administração ou de produtos legalmente apreendidos ou penhorados, ou para a alienação de bens imóveis prevista no art. 19, a quem oferecer o maior lance, igual ou superior ao valor da avaliação. (Redação dada pela Lei no 8.883, de 1994).

Percebe-se a universalidade característica do leilão, possibilitando a participação de quaisquer interessados. Vale observar ainda as peculiaridades da alienação dos bens imóveis da Administração nos moldes do artigo abaixo: 
Art. 19. Lei 8.666/1993 Os bens imóveis da Administração Pública, cuja aquisição haja derivado de procedimentos judiciais ou de dação em pagamento, poderão ser alienados por ato da autoridade competente, observadas as seguintes regras:

I - avaliação dos bens alienáveis;

II - comprovação da necessidade ou utilidade da alienação;

III - adoção do procedimento licitatório, sob a modalidade de concorrência ou leilão.

Art. 17. Lei 8.666/1993 A alienação de bens da Administração Pública, subordinada à existência de interesse público devidamente justificado, será precedida de avaliação e obedecerá às seguintes normas:

§ 6o Para a venda de bens móveis avaliados, isolada ou globalmente, em quantia não superior ao limite previsto no art. 23, inciso II, alínea "b" desta Lei, a Administração poderá permitir o leilão.

§ 7o Quando, por limitações do mercado ou manifesto desinteresse dos convidados, for impossível a obtenção do número mínimo de licitantes exigidos no § 3o deste artigo, essas circunstâncias deverão ser devidamente justificadas no processo, sob pena de repetição do convite.

§ 8o É vedada a criação de outras modalidades de licitação ou a combinação das referidas neste artigo.

Nessa medida, como se pode observar, o leilão é aplicável quando o valor dos bens for até R \$ 650.000,00 (Cunha Júnior, 2015, p. 481).

O STF permitiu a realização de leilão para formalizar a concessão de serviços públicos, no âmbito da desestatização, conforme art. $4^{\circ}, \S^{\circ}$, da Lei 9.491/97 (STF, Tribunal Pleno, MS 27.516/Df. Rel. Min. Ellen Gracie, j.22.10.2008 Dje-232, 05.12.2008 (Informativo de jurisprudência do STF n $525)$ ).

Deve-se atentar que a lei permite a hipótese de uma modalidade licitatória ser substituída por uma mais rigorosa. Matheus Carvalho (2015, p. 443) cita uma exceção ao proclamar que a lei possibilita a parcela e o uso de modalidade mais simples quando se tratar de modalidade específica que deve ser executada por pessoa diferente daquela que executa a proposta principal. 


\section{CAPÍTULO 2: PRINCÍPIOS E REGRAS DA CONTRATAÇÃO DIRETA E INDIRETA}

\subsection{Princípios}

Há duas particularidades na licitação e na contratação direta da Administração Pública imprescindíveis, são elas: a moralidade administrativa (guiar as condutas dos administradores, prevenindo condutas ímprobas) e a igualdade de oportunidade (Carvalho Filho, 2016, p. 252). A vantajosidade, a isonomia e o desenvolvimento nacional sustentável são os princípios fundamentais desses contextos, confundindo-se com os princípios presentes no rol do estatuto (Justen Filho, 2012, p. 443).

A partir dessas ilações, esse instituto constituído por princípios ${ }^{16} \mathrm{e}$ conceitos unívocos, aplicáveis a todos os tipos de licitação sejam nacionais, internacionais, financiadas por organismos internacionais de fomento e até mesmo na contratação direta que se certifica a perseguição da verdade real no processo administrativo. É pelo princípio do procedimento licitatório que a igualdade deve ser assegurada entre todos os interessados na contratação; e por fim, pelo princípio da publicidade é que se fornece as informações necessárias para os interessados (Souto, 1998, p. 27-29).

Tendo em vista que não há total consenso entre os doutrinadores sobre os princípios que se referem à licitação, cabe aqui analisar os principais tópicos referente à licitação. Abaixo estão transcritos os dispositivos essenciais que tratam do tema:

Art. 37. CF A administração pública direta e indireta de qualquer dos Poderes da União, dos Estados, do Distrito Federal e dos Municípios obedecerá aos princípios de legalidade, impessoalidade, moralidade, publicidade e eficiência e, também, ao seguinte: (Redação dada pela Emenda Constitucional nº 19, de 1998).

\footnotetext{
16 “Com efeito, o Direito como qualquer outra Ciência, não prescinde de princípios: proposições que lhe conferem coerência e unidade sistêmica, qualidades imprescindíveis para que qualquer conjunto integrado de conhecimentos adquira status científico". (Moreira Neto, 2008, p. 84)
} 
Art. 3o lei 8666/93 A licitação destina-se a garantir a observância do princípio constitucional da isonomia, a seleção da proposta mais vantajosa para a administração e a promoção do desenvolvimento nacional sustentável e será processada e julgada em estrita conformidade com os princípios básicos da legalidade, da impessoalidade, da moralidade, da igualdade, da publicidade, da probidade administrativa, da vinculação ao instrumento convocatório, do julgamento objetivo e dos que lhes são correlatos.

Sendo assim, os princípios referidos no art. 37 CF são os constitucionais e os do art. $3^{\circ}$ Lei 8666/1993 não menos importantes são os princípios específicos da licitação (Aragão, 2013, p. 294 e Medauar, 2005, p. 211). Vale fazer uma observação de alguns deles:

\subsubsection{Legalidade}

Princípio basilar da Administração Pública já que deve reger quaisquer atos do ente público. Reitera-se que a legalidade dos administradores é a legalidade estrita em que estes só podem executar aquilo que a lei permite (Santos, 2012, p. 516-517), dessemelhante da legalidade dos administrados em que se pode fazer tudo o que a lei não proíbe (Garcia, 2010, p. 4). As normas estipuladas no certame devem ser estritamente respeitadas.

O dispositivo do estatuto que trata do presente princípio é o transcrito abaixo:

Art. 4o Todos quantos participem de licitação promovida pelos órgãos ou entidades a que se refere o art. $1^{\circ}$ têm direito público subjetivo à fiel observância do pertinente procedimento estabelecido nesta lei, podendo qualquer cidadão acompanhar o seu desenvolvimento, desde que não interfira de modo a perturbar ou impedir a realização dos trabalhos.

Parágrafo único. O procedimento licitatório previsto nesta lei caracteriza ato administrativo formal, seja ele praticado em qualquer esfera da Administração Pública.

Quem pode alegar o direito em estudo não se limita aos que participam da licitação, mas também aqueles que queiram participar e até mesmo os que tiveram acesso negado de forma indevida, por violação dos princípios basilares (Mello, 2012, p. 541).

Abarca a aplicação desse princípio ao averiguá-lo na contratação direta, seja na dispensa, na inexigibilidade ou na licitação dispensada. Situações essas 
que caracterizam exceções da regra geral do procedimento licitatório em se tratando da contratação executada pela Administração Pública. Sendo assim, seja qual for a forma da contratação direta, deve se submeter à legalidade.

Nota-se a iminência de uma corrente que trata do princípio da juridicidade não limitando a Administração Pública às condições da lei formal. No entanto, está sim interligada ao sistema jurídico como um todo, sendo a Carta Magna a unidade base do regime jurídico administrativo. É por essa linha de pensamento que baseia a corrente de constitucionalização do direito administrativo (Binenbojm, 2006. p. 137-144).

\subsubsection{Moralidade e Impessoalidade}

Princípios interligados ao da impessoalidade é o princípio da ética, o da boa-fé, o da isonomia e o do julgamento objetivo. A impessoalidade inviabiliza qualquer tipo de preferência entre os licitantes (Garcia, 2010, p. 04-05).

Segundo Marçal Justen Filho (2012, p. 446) a impessoalidade está relacionada à isonomia e caracteres pessoais como abaixo explicito:

\footnotetext{
A impessoalidade é a emanação da isonomia, da vinculação à lei e ao ato convocatório e da moralidade. Indica vedação a distinções fundadas em caracteres pessoais dos interessados. Ao menos os caracteres pessoais devem refletir diferenças efetivas e concretas (que sejam relevantes para os fins da licitação).
}

Enquanto para esse autor a impessoalidade advém da isonomia (no mesmo sentido Santos, 2012, p. 517), da legalidade, da vinculação ao edital e da moralidade, havendo uma definição mais abrangente, na ótica de Celso Antônio Bandeira de Mello o conceito apresenta forma mais restrita, baseia-se na impossibilidade de haver favoritismos na contratação. Ressalta que na licitação todos devem ser tratados de forma neutra, acrescenta que "tal princípio não é senão uma forma de designar o princípio da igualdade de todos perante a Administração" (Mello, 2012, p. 542).

Esses princípios também devem ser aplicados na contratação direta, já que seja na dispensa, na inexigibilidade ou na licitação dispensada deve haver 
submissão desses preceitos a fim de se excetuar a licitação de forma ética. A não aplicabilidade é tipificado como crime seja na lei em estudo, no Código Penal ou até mesmo na Lei de Improbidade Administrativa (Aragão, 2013, p. 299).

A inexigibilidade, por exemplo, deve ocorrer quando for inviável a competição, caso o texto legal seja violado quanto aos seus requisitos, infringindo ora o princípio da moralidade ora da impessoalidade, pode o violador ser submetido a sanções penais e administrativas aplicadas pelo órgão jurisdicional. Na licitação dispensável, a competição é viável, são hipóteses taxativas previstas em lei permitindo a contratação direta discricionariamente. Sendo assim, em qualquer de suas possibilidades deve estar presente a moralidade e a impessoalidade para que seja válida. Aplicando tais princípios também na licitação dispensada, hipóteses essas vinculadas e restritas à disposição legal.

Finalmente, acentua-se a importância da pesquisa de preços, instrumento essencial para se justificar uma ínfima moralidade e impessoalidade. É através dela que se evita desvio de finalidade e abuso de poder ao se tratar da contratação com a Administração Pública. É o meio que se garante tal impessoalidade e a isonomia através da competição, havendo, assim, igualdade de condições. Nesse viés, a Administração Pública contrata com aquele que oferecer um preço justo dentro das condições de mercado, de forma que garanta o interesse público.

Chama-se a atenção o desenvolvimento pela UnB de dois softwares (DANTAS, Disponível em: <http://www.unbciencia.unb.br/humanidades/88ciencias-contabeis/511-unb-lanca-sistema-de-governanca-para-ajudar-setorpublico-a-gerir-gastos>.), chamados sicgesp e recasp, que permite um panorama exato dos custos e produtividades da Administração Pública a partir de informações e conteúdos de diferentes governos locais, nos moldes da lei de responsabilidade fiscal e lei de acesso à informação. O objetivo desses softwares são o de conter gastos e otimizar a produtividade da Administração Pública. A contar desses instrumentos, gestores preveem maior facilidade na gestão a partir de uma análise do desempenho da própria Administração, permitindo, dessa forma, maior eficiência no que se trata de pesquisa de preços. 


\title{
2.1.3. Igualdade entre os licitantes
}

O princípio em tese consiste na igualdade de todos os interessados em contratar com a Administração que devem competir em paridade de condições, sem predileções entre eles que não sejam extensivas ao outro, suscitando, assim tratamento impessoal aos seus participantes (Carvalho Filho, 2016, p. 254-255 e Santos, 2012, p. 518).

\begin{abstract}
Art. 3o A licitação destina-se a garantir a observância do princípio constitucional da isonomia, a seleção da proposta mais vantajosa para a administração e a promoção do desenvolvimento nacional sustentável e será processada e julgada em estrita conformidade com os princípios básicos da legalidade, da impessoalidade, da moralidade, da igualdade, da publicidade, da probidade administrativa, da vinculação ao instrumento convocatório, do julgamento objetivo e dos que lhes são correlatos.
\end{abstract}

§ 1o É vedado aos agentes públicos:

I - admitir, prever, incluir ou tolerar, nos atos de convocação, cláusulas ou condições que comprometam, restrinjam ou frustrem o seu caráter competitivo, inclusive nos casos de sociedades cooperativas, e estabeleçam preferências ou distinções em razão da naturalidade, da sede ou domicílio dos licitantes ou de qualquer outra circunstância impertinente ou irrelevante para o específico objeto do contrato, ressalvado o disposto nos $\S \S 5$ o a 12 deste artigo e no art. 3o da Lei no 8.248, de 23 de outubro de 1991; (Redação dada pela Lei $\mathrm{n}^{\circ} 12.349$, de 2010)

II - estabelecer tratamento diferenciado de natureza comercial, legal, trabalhista, previdenciária ou qualquer outra, entre empresas brasileiras e estrangeiras, inclusive no que se refere a moeda, modalidade e local de pagamentos, mesmo quando envolvidos financiamentos de agências internacionais, ressalvado o disposto no parágrafo seguinte e no art. 3o da Lei no 8.248, de 23 de outubro de 1991.

O descumprimento do presente princípio configura abuso de poder, já que a Administração Pública deve sempre zelar pela imparcialidade e pelo interesse público. Sua violação é motivo de anulação dos atos infratores.

Salienta-se que José dos Santos Carvalho Filho (2016, p. 257) faz menção ao princípio da competitividade como princípio correlato ao da igualdade. É devido à competição que há a disputa entre os licitantes. Assim, sem a disputa estaria comprometido o próprio princípio da igualdade.

Rafael Oliveira (2015, p. 31-32) frisa um pressuposto da isonomia: “... tratamento desigual entre as pessoas que não se encontram na mesma situação 
fático-jurídica (tratamento desigual aos desiguais), desde que respeitado o princípio da proporcionalidade".

Por fim, ressalta-se que o princípio da igualdade passa a ser característica a priori da contratação direta, pois para se chegar às possibilidades da "não licitação", houve previamente uma avaliação da possibilidade de licitar. Assim sendo, seja pela inviabilidade de competição na inexigibilidade licitatória; na licitação dispensável, com seu caráter discricionário; e nas hipóteses vinculadas da licitação dispensada, situações interpretadas pelo legislador que condescendeu a contratação direta a partir da inviabilidade de competição cumprindo o princípio da igualdade.

\subsubsection{Publicidade de seus atos e sigilo}

É a partir desse princípio, inerente ao dever de transparência (Aragão, 2013, p. 299) que se procede o amplo acesso à informação, a importância da divulgação e do conhecimento da licitação, condicionando esse fenômeno à sua eficácia. Permite o amplo acesso aos interessados e consente a verificação dos atos (Santos, 2012, p. 520-521).

Art. 3o A licitação destina-se a garantir a observância do princípio constitucional da isonomia, a seleção da proposta mais vantajosa para a administração e a promoção do desenvolvimento nacional sustentável e será processada e julgada em estrita conformidade com os princípios básicos da legalidade, da impessoalidade, da moralidade, da igualdade, da publicidade, da probidade administrativa, da vinculação ao instrumento convocatório, do julgamento objetivo e dos que lhes são correlatos.

§ 3o A licitação não será sigilosa, sendo públicos e acessíveis ao público os atos de seu procedimento, salvo quanto ao conteúdo das propostas, até a respectiva abertura.

Art. 43. A licitação será processada e julgada com observância dos seguintes procedimentos:

$\S 1$ A A abertura dos envelopes contendo a documentação para habilitação e as propostas será realizada sempre em ato público previamente designado, do qual se lavrará ata circunstanciada, assinada pelos licitantes presentes e pela Comissão. 
Aponta-se que o princípio do sigilo na apresentação das propostas está intrinsicamente relacionado ao princípio em questão. Isso ocorre porque a regra geral é a publicidade dos atos, no entanto, há determinados formalismos como o da abertura dos envelopes nos moldes do art. $43 \S 1^{\circ}$ Lei 8.666/1993 dispondo a necessidade de sigilo até a data designada para a abertura em questão. A violação desse sigilo decorre no art. 94 Lei 8.666/1993 que dispõe um ilícito penal: a abertura dos envelopes antecipada.

Art. 94. Devassar o sigilo de proposta apresentada em procedimento licitatório, ou proporcionar a terceiro o ensejo de devassá-lo:

Pena - detenção, de 2 (dois) a 3 (três) anos, e multa.

$\mathrm{Na}$ contratação direta esses princípios estão presentes a partir das hipóteses expressas na lei 8.666/1993, assim, a inexigibilidade de licitação, com seu rol exemplificativo do art. 25 do Estatuto; a dispensa de licitação, com seu rol taxativo no art. 24 da lei e; por fim, a licitação dispensada, rol também taxativo, presente no art. 17 do mesmo. Nesse diapasão, está à disposição de todos os interessados as hipóteses em que não há licitação, sendo que a aplicação de qualquer das três hipóteses de contratação direta deve ser obrigatoriamente fundamentada.

\subsubsection{Probidade Administrativa}

Todos aqueles que têm vínculo com a administração pública devem apresentar condutas $\operatorname{probas}^{17}$, compatíveis com a ética e com a boa-fé caracterizando também o respeito ao princípio da moralidade já explicitado no item 2.1.B. Dessa forma, o mandamento constitucional abaixo transcreve as consequências em hipótese de se verificar o desrespeito de tais princípios:

\footnotetext{
17 “O funcionário deve servir a Administração com honestidade procedendo no exercício das suas funções sempre no intuito de realizar os interesses públicos, sem aproveitar os poderes ou facilidades delas decorrentes em proveito pessoal ou de outrem a quem queira favorecer ... o dever de probidade de probidade impõe assim ao funcionário uma conduta de absoluta isenção, de modo que não seja suspeito de prevaricar, de deixar-se corromper ou de por outro modo ser infiel à entidade servida e aos interesses gerais que the cumpre realizar e defender" (Caetano, 1983, p. 749)
} 
Art. $37 \S 4^{\circ}$ Os atos de improbidade administrativa importarão a suspensão dos direitos políticos, a perda da função pública, a indisponibilidade dos bens e o ressarcimento ao erário, na forma e gradação previstas em lei, sem prejuízo da ação penal cabível.

Conclui-se que a licitação deve ser norteada seja por atos honestos e sérios. Como afirma Marçal Justen Filho (2012, p. 446) "os princípios aplicam-se tanto à conduta do agente da Administração Pública como à dos próprios licitantes. A moralidade compreende também a boa-fé". Mesmo em suposições de contratação direta, o princípio da probidade administrativa deve conduzir as condutas de todos os agentes públicos responsáveis pelos seus respectivos procedimentos.

Não há consenso sobre a definição escorreita do princípio da "probidade". Há uma corrente, por exemplo, que trata a probidade como um subprincípio da moralidade, destacando Wallace Paiva Martins Júnior (TAFNER, Disponível em: $<$ http://www.mpsp.mp.br/portal/page/portal/cao_cidadania/Improbidade_Admini strativa/Doutrina_Improbidade/3-improbeaus\%C3\%AAnciadepreju\%C3\%ADzo. htm >). Já Emerson Garcia (GARCIA, Disponível em < http://www.femperj.org.br/pesquisas/artigos.php >.) e Rogério Pacheco Alves tratam a probidade como uma definição mais ampla, reiterando a polêmica da definição.

\subsubsection{Vinculação ao instrumento convocatório}

O próprio nome do princípio é autoexplicativo, nada obstante Hely Lopes Meirelles (2016, p. 321) aclara em poucas palavras: "o edital é a lei interna da licitação". O art. baixo citado esclarece:

Art. 41. A Administração não pode descumprir as normas e condições do edital, ao qual se acha estritamente vinculada.

Esse artigo traz à tona o chamado princípio da inalterabilidade do edital conexo com o princípio da vinculação ao instrumento convocatório, com o da publicidade e com o princípio da maior vantajosidade gerando segurança jurídica (Santos, 2012, p. 522). Observa-se na decisão do TCU transcrita abaixo: 
O disposto no caput do art. 41 da lei 8666/1993, que proíbe a Administração de descumprir as normas e o edital, deve ser aplicado mediante a consideração dos princípios basilares que norteiam o procedimento licitatório, dentre eles o da seleção da proposta mais vantajosa (Acórdão 3381/2013 - Plenário, 4.1.2013. Info TCU 180).

Posto isto, o procedimento está vinculado ao edital, não devendo haver desvios ou a invocação de atos discricionários de análises subjetivas, assim, não se revoga o certame depois que ele se iniciou (Aragão, 2013, p. 296). Entretanto, cabe uma análise do caso concreto, já que não se trata de um princípio absoluto. Assim sendo, é aplicável o princípio da razoabilidade se for o caso de elaborar aditamentos.

Acrescenta-se que a modificação editalícia deve ser da forma que ocorreu a publicação do edital, e também em conformidade com a reabertura do prazo. Este não ocorre em caso de alterações técnicas que nada represente na proposta da licitação. Conclui-se que só há a reabertura do prazo em situações de modificação da natureza proposta.

Maria Sylvia Zanela Di Pietro (2014, p. 374) elucida acerca do instrumento convocatório no que tange ao princípio da isonomia e em especial a força da vinculação do citado instrumento:

Pela licitação, a Administração abre a todos os interessados que se sujeitem às condições fixadas no instrumento convocatório, a possibilidade de apresentação de proposta. Quando a Administração convida os interessados pela forma de convocação prevista na lei (edital ou carta-convite), nesse ato convocatório vêm contidas as condições básicas para participar da licitação, bem como as normas a serem observadas no contrato que se tem em vista celebrar; o atendimento à convocação implica a aceitação dessas condições por parte dos interessados. Daí a afirmação segundo a qual o edital é a lei da licitação e, em consequência, a lei do contrato. Nem a Administração pode alterar as condições, nem o particular pode apresentar propostas ou documentação em desacordo com o exigido no ato de convocação, sob pena de desclassificação ou inabilitação, respectivamente.

Será inválido qualquer ato que confronte com as disposições editalícias. Rafael Oliveira (2015, p. 32) ressalta: "Trata-se da aplicação específica do princípio da legalidade, razão pela qual a não observância das regras fixadas no instrumento convocatório acarretará a ilegalidade do certame". O instrumento editalício tem o objetivo de garantir segurança para os licitantes e licitados. Em 
qualquer tipo de violação, o transgressor será desclassificado e terá que se submeter às sanções previstas na legislação.

\subsubsection{Julgamento objetivo}

Princípio também conhecido como "objetividade decisória" (Aragão, 2013, p. 296) está relacionado ao princípio da vinculação ao instrumento convocatório. Tudo aquilo previsto e disposto no edital deve ser formalmente executado, não havendo espaço para relações pessoais. Artigos que encontram esse princípio de forma expressa:

Art. 44. No julgamento das propostas, a Comissão levará em consideração os critérios objetivos definidos no edital ou convite, os quais não devem contrariar as normas e princípios estabelecidos por esta Lei.

Art. 45. O julgamento das propostas será objetivo, devendo a Comissão de licitação ou o responsável pelo convite realizá-lo em conformidade com os tipos de licitação, os critérios previamente estabelecidos no ato convocatório e de acordo com os fatores exclusivamente nele referidos, de maneira a possibilitar sua aferição pelos licitantes e pelos órgãos de controle.

Esse preceito impede que haja qualquer caráter subjetivista, sentimentalistas e propósitos pessoais na licitação (Santos, 2012, p. 522-523 e Mello, 2012, p. 547). Esse princípio deve ser respeitado mesmo em situações de empate entre duas ou mais propostas. Nessa situação, por meio de sorteio que haverá o desempate (art. $45 \$ 2^{\circ}$ Lei 8.666/1992)”. Está vedada a oferta de vantagens.

O edital deve ser respeitado de forma impessoal. Declara Matheus Carvalho (2015, p. 433) que "Com efeito, não pode ser utilizado, para fins de escolha do vencedor, nenhum outro fator de análise que não aqueles expressamente definidos no instrumento convocatório". Alexandre de Aragão (2013, p. 297) por sua vez confirma "vê-se, portanto, que a discricionariedade da Administração em adotar, por exemplo, este ou aquele critério de julgamento é limitada pela necessidade de buscar a maior objetividade possível no processamento da licitação". 


\subsubsection{Adjudicação compulsória:}

Nesse princípio a Administração Pública passa a estar obrigada a contratar com o legítimo vencedor da licitação. Tal princípio está bem definido nos artigos abaixo.

Art. 50. A Administração não poderá celebrar o contrato com preterição da ordem de classificação das propostas ou com terceiros estranhos ao procedimento licitatório, sob pena de nulidade.

Art. 64. A Administração convocará regularmente o interessado para assinar o termo de contrato, aceitar ou retirar o instrumento equivalente, dentro do prazo e condições estabelecidos, sob pena de decair o direito à contratação, sem prejuízo das sanções previstas no art. 81 desta Lei.

Maria Sylvia Zanella Di Pietro (2014, p. 388) desmitifica a expressão "adjudicação compulsória" ao expor:

Em verdade, a expressão adjudicação compulsória é equívoca, porque pode dar a ideia de que, uma vez concluído o julgamento, a Administração está obrigada a adjudicar; isto não ocorre, porque a revogação motivada pode ocorrer em qualquer fase da licitação. Tem-se que entender o princípio no sentido de que, se a Administração levar o procedimento a seu termo, a adjudicação só pode ser feita ao vencedor; não há um direito subjetivo à adjudicação quando a Administração opta pela revogação do procedimento.

Ela chama a atenção para o princípio da indisponibilidade do interesse público, sendo este o responsável pela vinculação da licitação à administração pública e aos entes a ela vinculados. Maria Sylvia Zanella Di Pietro (2014, p.377-392), em sua classificação principiológica acrescenta os princípios da legalidade, impessoalidade e moralidade conforme explícito no art. 37 da Carta Magna. Soma-se a estes o da ampla defesa, o da razoabilidade, o da motivação, o da participação popular decorrendo estes últimos da lei 8666/1993 e de outras leis esparsas. Ela certifica o princípio da sustentabilidade da licitação ou princípio da licitação sustentável (Di Pietro, 2014, p. 389).

Assim como no princípio de vinculação ao instrumento convocatório, no do julgamento objetivo e neste que trata da adjudicação compulsória, todos eles não estão presentes na contratação direta já que nesta não há edital, nem 
julgamento, nem adjudicação compulsória. Sendo assim, estão ausentes das hipóteses em que não há a contratação pela Administração Pública.

\subsubsection{Licitação Sustentável}

O princípio da licitação sustentável destacado por Maria Sylvia Zanella Di Pietro (2014, p. 389) busca a preservação do meio ambiente. Para ela, esse princípio permite haver exigências que busquem preservar o ecossistema, harmonizando-se com o princípio da isonomia, no mesmo sentido, Cunha Júnior expõe. (2015, p. 465).

Desse modo, auferiu-se o presente princípio de maior notoriedade com o advento da lei 12.349/2010 que alterou o art. $3^{\circ}$ da lei 8.666/1993, regulamentado pelo Decreto Presidencial n ${ }^{\circ}$ 7.746/2012, fazendo com que a licitação se destinasse a garantir o desenvolvimento nacional sustentável, passando, a Administração Pública a estar obrigada a realizar contratações em prol das licitações sustentáveis (Aragão, 2013, p. 299-301).

Marçal Justen Filho (2012, p. 443) abona que "rigorosamente, a promoção do desenvolvimento nacional sustentável é obtida não por meio da licitação, mas por via da contratação propriamente dita". Ele justifica tal assertiva com base na licitação possuir uma estrutura que promova o crescimento econômico social de forma compatível com a preservação do meio ambiente.

É bem verdade que esse princípio está presente na contratação direta, dado que as situações em que não há a licitação devem ser amparadas por aspectos que preservem o meio ambiente através de opções de hipóteses mais sustentáveis, promovendo maior equilíbrio ambiental em prol da finalidade precípua do Direito Administrativo: o interesse público.

A partir dessa perspectiva se observa que esse fenômeno de sustentabilidade é mais antigo que a Lei de Licitações de 1993. O conceito de "desenvolvimento sustentável” veio à tona em 1987 no Relatório Brundtland preparado pela Comissão Mundial Sobre Meio Ambiente e Desenvolvimento da Organização das Nações Unidas (ONU). Este relatório tem como função 
precípua desenvolver às necessidades correntes, preservando as gerações futuras em suas necessidades futuras (Valente, 2011. p. 13).

Finalmente, Marcos Juruena Villela Souto (1998, p. 29) sistematiza importantes princípios acima analisados:

Por força da legalidade, o procedimento licitatório deve obedecer, rigorosamente aos padrões definidos na lei e atos que regulamentam; pela moralidade administrativa, exige-se uma preocupação ética da administração com a seriedade do procedimento e do seu resultado, tanto perante os licitantes como perante a sociedade; o princípio da impessoalidade exige da Administração um tratamento isonômico a todos os interessados, sem favores ou benefícios a um licitante em detrimento dos demais; por fim, o princípio da publicidade impõe a transparência dos atos da licitação, resguardando o sigilo da proposta até o momento do julgamento (grifo nosso).

Reitera-se que todos as proposições ${ }^{18}$ destacadas no trecho acima são aplicáveis às hipóteses de contratação direta como já analisadas. Além de os princípios indicarem objetivos, é de onde se examinam as orientações práticas para resultados legítimos e eficientes (Moreira Neto, 2008, p. 93).

\footnotetext{
18 "Sob o ponto de vista gnosiológico, os princípios são proposições abstratas de segundo grau, como abstrações inferidas das leis, que, por sua vez, são proposições abstratas de primeiro grau, porque se dessumem diretamente dos fatos para evidenciar alguma invariância, que os possa distinguir" (Moreira Neto, 2008, p. 84)
} 


\section{CAPÍTULO 3: CONTRATAÇÃO DIRETA: LICITAÇÃO DISPENSÁVEL}

\subsection{Exceções do dever de licitar}

Tendo em vista que o conceito da licitação, seus aspectos constitucionais, objetos e objetivos, sujeitos, modalidades e alguns princípios relacionados foram expostos, diversas conclusões já podem ser analisadas.

Diante do apresentado, observou-se a obrigatoriedade da licitação quando a Administração Pública contrata com terceiros, como regra geral. Ocorre que há situações em que ela não realiza a licitação, é a partir dessa situação que se inicia uma análise das possibilidades em que tal excepcionalidade ocorre ${ }^{19}$.

A exceção da não licitação se divide primordialmente em três espécies, são elas: dispensa, inexigibilidade e licitação dispensada. Esta última está disposta no art. 17 lei 8.666/1993 em que a conduta é vinculada, sendo a Administração obrigada a nada fazer. Na inexigibilidade a competição é inviável tornando a licitação inexigível. Por fim, há a dispensa em que há viabilidade de licitação, porém a conduta é discricionária, cabendo a Administração realizar ou não a contratação direta.

Na vigência do DL 2.300/1986, a corrente majoritária evidenciava quatro formas de contratação direta, Rafael Oliveira $(2015$, p.61) comenta sobre o tema:

... a) licitação dispensada: a própria lei dispensa a licitação; b) licitação dispensável: a lei autoriza que a autoridade administrativa dispense, por decisão motivada, a licitação; c) licitação inexigível: quando não há possibilidade de competição; e d) licitação vedada: a lei proíbe a licitação em caso de comprometimento da segurança nacional.

Todavia, a hipótese de licitação vedada ('comprometimento da segurança nacional'), prevista no art. $23 \S 1^{\circ}$, do DL 2.300/1986 é tratada na atual legislação como caso de dispensa de licitação (art. 24, IX, da Lei 8.666/1993). Desta forma, a atual legislação não consagra mais a licitação vedada.

\footnotetext{
19 “Os casos de contratação direta, arrolados primeiramente no Decreto-lei 200/1967, posteriormente no Decreto-lei 2.300/1986 e, atualmente, na Lei 8.666/1993, com as modificações mencionadas, e em rol crescente, na realidade, no mais das vezes, não impediriam a Administração de licitar. Na verdade, existe a faculdade de contratar diretamente, desde que se verifiquem as hipóteses legais, salvo os casos de inexigibilidade, onde haverá livre eleição". (Figueiredo, 2008, p. 474).
} 
Antes da análise dos tópicos da contratação direta propriamente dita, vale transcrever uma importante consideração do Marcos Juruena Villela Souto (1998, p. 38) sobre o autorizador de despesa:

\begin{abstract}
É a autoridade definida em lei com poderes para tomar a decisão política de assumir obrigações e direitos em nome de entidades da Administração; em regra são o Presidente, Vice-Presidente, Ministros, Procuradores-Gerais, Governadores, Vicegovernadores, Prefeitos, Vice-Prefeitos, Secretários de Estado e de Municípios, Presidentes de Autarquias, Empresas Públicas, Sociedades de Economia Mista e Fundações. Portanto, tais acesso autoridades assinam os contratos e, antes, o edital ou as ratificações de dispensas e inexigibilidades de licitação. Ao autorizador da despesa cabe homologar a licitação e julgar os recursos, assinar os empenhos, salvo delegação de poderes. Deve prestar contas de sua gestão ao Tribunal de Contas.
\end{abstract}

No presente capítulo haverá uma análise dos casos de dispensa e no seguinte serão tratados os casos de licitação dispensável e de sua inexigibilidade.

\title{
3.2. Dispensa de licitação
}

A dispensa de licitação presente na lei 8.666/1993 apresenta um rol taxativo. São nessas situações em que há uma possibilidade de uma contratação direta (Santos, 2012, p. 531). Passa-se neste tópico a análise pormenorizada dos incisos do art. 24 lei 8.666/1993 na classificação elaborada por José dos Santos Carvalho Filho (2016, p. 261-281), muito semelhante a do Rafael Carvalho:

\subsubsection{Critério de valor}

Art. 24. É dispensável a licitação:

I - para obras e serviços de engenharia de valor até $10 \%$ (dez por cento) do limite previsto na alínea "a", do inciso I do artigo anterior, desde que não se refiram a parcelas de uma mesma obra ou serviço ou ainda para obras e serviços da mesma natureza e no mesmo local que possam ser realizadas conjunta e concomitantemente;

II - para outros serviços e compras de valor até $10 \%$ (dez por cento) do limite previsto na alínea "a", do inciso II do artigo anterior e para alienações, nos casos previstos nesta Lei, desde que não se refiram a parcelas de um mesmo serviço, compra ou alienação de maior vulto que possa ser realizada de uma só vez; 
$\S 1$ o Os percentuais referidos nos incisos I e II do caput deste artigo serão $20 \%$ (vinte por cento) para compras, obras e serviços contratados por consórcios públicos, sociedade de economia mista, empresa pública e por autarquia ou fundação qualificadas, na forma da lei, como Agências Executivas.

Os dois primeiros incisos tratam do critério de valor, no entanto, se for mais adequado, pode a administração realizar licitação ainda assim. O legislador buscou abranger os princípios da economicidade e da eficiência administrativa. $\mathrm{Na}$ dispensa não há obrigatoriedade de não licitar. Não é possível fracionar contratações de forma que haja a dispensa, pode até haver tal fracionamento, mas de forma alguma com o objetivo de acarretar a contratação direta.

$\mathrm{O}$ entendimento do STJ e da PGE/RJ respectivamente sobre o tema se enquadra no seguinte:

Não se amolda à hipótese de licitação prevista no art. 24 II, da lei 8.666/93 a situação em que, contratada organizadora para a realização de concurso público por valor inferior ao limite previsto no referido dispositivo, tenha-se verificado que a soma do valor do contrato com o total arrecadado a título de taxa de inscrição supere o limite de dispensa previsto no aludido inciso. (REsp 1.356.260-SC, Rel. Min. Humberto Martins, 7.2.13. $2^{\mathrm{a}}$ T. (Info 516)).

Enunciado n. ${ }^{\circ}$ 17-PGE: Na contratação direta com fundamento no art. 24, I e II, da Lei $\mathrm{n}^{\circ} 8.666 / 93$ deve ser realizada prévia pesquisa de mercado, bem como ser considerado todo o exercício financeiro. Publicado: DO 06/02/2007 p. 20.

Deve-se atentar com o $\S 1^{\circ}$ que dispõe as exceções, isto é, hipóteses de dispensa em função do valor em dobro. O dispositivo expõe que as empresas públicas, sociedades de economia mista, agências executivas e consórcios públicos estão dispensados de licitar em contratações no percentual de até $20 \%$ do valor do convite.

A página a seguir apresenta um quadro esquemático elaborado por Rafael Carvalho $(2015$, p.88) para a análise a fim de tornar o conteúdo da forma mais didática: 


\begin{tabular}{|c|c|c|c|c|}
\hline Entidades & $\begin{array}{l}\text { Entidades } \\
\text { administrativas: } \\
\text { dispensa de } \\
\text { licitação (art. } \\
24, \text { I e II) }\end{array}$ & 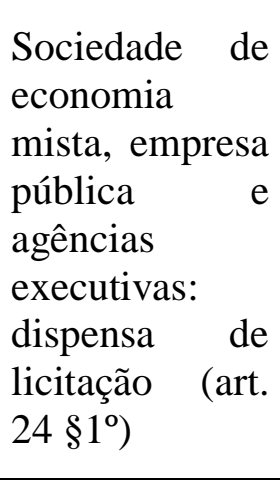 & $\begin{array}{l}\text { Consórcios } \\
\text { públicos } \\
\text { formados por } \\
\text { até três Entes } \\
\text { da Federação: } \\
\text { Dispensa de } \\
\text { licitação (art. } \\
238^{\circ} \text {, e } 24 \\
\$ 1^{\circ}\end{array}$ & 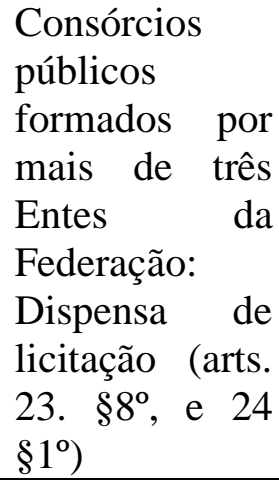 \\
\hline $\begin{array}{l}\text { Obra e } \\
\text { serviços de } \\
\text { engenharia }\end{array}$ & $\begin{array}{l}\text { Até } \\
15.000,00\end{array}$ & $\begin{array}{l}\text { Até } \\
30.000,00\end{array}$ & $\begin{array}{l}\text { Até } \\
60.000,00\end{array}$ & $\begin{array}{l}\text { Até } \quad \text { R\$ } \\
90.0000,00\end{array}$ \\
\hline $\begin{array}{l}\text { Compras e } \\
\text { serviços }\end{array}$ & $\begin{array}{l}\text { Até } \\
8.000,00\end{array}$ & $\begin{array}{ll}\text { Até } & \mathrm{R} \$ \\
16.000,00 & \end{array}$ & Até 30.000,00 & $\begin{array}{ll}\text { Até } & \mathrm{R} \$ \\
48.000,00 & \end{array}$ \\
\hline
\end{tabular}

Percebe-se que a intenção da licitação é a competição máxima possível de empresas a fim de selecionar a proposta mais vantajosa. No seu tipo "menor valor", avalia-se a vantajosidade nas conjunturas econômicas, vinculado aos preceitos do edital. É nesse contexto que a licitação exerce função de regular o mercado $^{20}$, dado que ao selecionar esse critério de "menor valor", deve-se optar pela predileção menos custosa, optando por menores gastos Estatais, impactando, assim, de forma menos onerosa nos cofres públicos. Dessa forma, através desse e de outros mecanismos licitatórios é viável atenuar os efeitos de crises econômicas (Ferraz, 2010, p.1-2).

\subsubsection{Situações excepcionais}

III - nos casos de guerra ou grave perturbação da ordem;

Esse inciso pode ser claramente explicado por José dos Santos (2016, p. 264) e pelo enunciado da PGE/RJ respectivamente:

\footnotetext{
${ }^{20}$ Art. 174. Como agente normativo e regulador da atividade econômica, o Estado exercerá, na forma da lei, as funções de fiscalização, incentivo e planejamento, sendo este determinante para o setor público e indicativo para o setor privado.
} 
Guerra é o conflito que põe em risco a soberania, e sua declaração é privativa do Presidente da República com autorização ou referendo do Congresso Nacional (art. 84 CF). Perturbação da ordem é a situação que afeta a paz e a disciplina social e política, gerando as medidas de estado de defesa (art. 136) e estado de sítio (art. 137 I CF). Todavia não basta qualquer comoção interna; é preciso que seja caracterizado como grave para justificar a dispensa.

Enunciado n. ${ }^{\circ} 20$-PGE:

1. A emergência, a ensejar dispensa de licitação, é um conceito jurídico indeterminado a ser valorado pelo administrador diante das especificidades do caso concreto, observados, em especial, os princípios da razoabilidade, moralidade e eficiência.

2. A emergência decorrente da falta de planejamento, incúria ou desídia do agente público não exclui a incidência do art. 24, inciso IV, da Lei n. ${ }^{\circ} 8.666 / 93$, mas deve ser objeto de rigorosa apuração com vistas à identificação dos responsáveis e aplicação das sanções cabíveis.

3. A contratação direta (art. 24, inciso IV, da Lei n. ${ }^{\circ}$ 8.666/93) deve ser efetivada somente para a aquisição de bens e serviços estritamente necessários ao saneamento da situação emergencial, cabendo à autoridade administrativa iniciar imediatamente o procedimento licitatório, adotando as providências necessárias à regularização da contratação.

4. O prazo do contrato emergencial deve ser dimensionado considerando apenas o tempo necessário para sanar a situação de urgência, limitado este a 180 (cento e oitenta) dias.

5. Se a situação emergencial persistir ao final do contrato e ante a vedação da prorrogação, a solução é a formalização de nova contratação com base no art. 24, inciso IV, da Lei n. ${ }^{\circ} 8.666 / 1993$, desde que, justificadamente, não seja possível realizar uma licitação durante o período ou adotar as providências necessárias à regularização da contratação".

Publicado: DO 07/05/2009 Pág. 21

\section{O inciso em questão está intimamente ligado com o seu sucessor, como se} observa a partir da transcrição abaixo:

IV - nos casos de emergência ou de calamidade pública, quando caracterizada urgência de atendimento de situação que possa ocasionar prejuízo ou comprometer a segurança de pessoas, obras, serviços, equipamentos e outros bens, públicos ou particulares, e somente para os bens necessários ao atendimento da situação emergencial ou calamitosa e para as parcelas de obras e serviços que possam ser concluídas no prazo máximo de 180 (cento e oitenta) dias consecutivos e ininterruptos, contados da ocorrência da emergência ou calamidade, vedada a prorrogação dos respectivos contratos; 
O inciso IV trata de contratação em situações de urgência sem ter sido causada pelo Estado. Se a situação for ensejada por um agente público, deve ser responsabilizada pelo mesmo, assim, a Administração irá contratar diretamente (Carvalho, 2015, p. 487).

Importante entendimento do TCU sobre o tema: "O Tribunal de Contas da União dispensa a licitação em caso de emergência ou calamidade pública (art. 24 IV, lei 8666/93), apenas se o objeto da contratação for o meio adequado, eficiente e efetivo de afastar o risco iminente detectado" (Acórdão1987/15Plenário ).

O plenário sintetiza o entendimento do TCU (acórdão 1.599/2011) no seguinte sentido:

\begin{abstract}
A dispensa de licitação prevista no inciso IV do art. 24 da lei 8.666/93 não distingue a emergência real, resultante do imprevisível, daquela resultante da incúria ou inércia administrativa, cabendo a utilização do dispositivo desde que devidamente caracterizada a urgência de atendimento a situação que possa ocasionar prejuízo ou comprometer a segurança de pessoas, obras, serviço, equipamentos e outros bens, públicos ou particulares.
\end{abstract}

A calamidade se caracteriza a partir de uma situação natural ou não, que destrói ou põe em risco a vida, a saúde ou até mesmo os bens de parte da sociedade. O mais comum é derivar de fatores naturais como os climáticos. Assim, há a dispensa para agilizar a contratação por uma necessidade de um procedimento rápido. Já na emergência é primordial o caráter de urgência no atendimento de modo que não haja prejuízo do interesse público (Carvalho Filho, 2016, p. 264).

É notável elucidar a alínea em estudo a uma tragédia ocorrida em uma ciclovia que desabou na Avenida Niemeyer no Rio de Janeiro matando duas pessoas em abril de 2016. As construtoras da ciclovia tiveram cerca de $46 \%$ dos seus contratos fixados com a Prefeitura do Rio de Janeiro por dispensa de concorrência, executando a contratação direta sob o fundamento do inciso em questão "obras emergenciais". Manoel Messias Peixinho alertou que a contratação direta na hipótese em questão deve ser efetuada quando o valor da obra não exceder R $\$ 8.000$ ou em situações de emergências e calamidades 
públicas. Acrescenta que não deve haver a dispensa de licitação se o instituto não for aplicado nos moldes da lei 8.666/1993 de forma que tenha o intuito de beneficiar determinada empresa, lesando o princípio da competitividade. Assim, só deve haver a dispensa em situações excepcionais conforme previsto em lei (FANTTI, 2016, Disponível em: < http://odia.ig.com.br/rio-de-janeiro/2016-0425/quase-metade-dos-contratos-da-concremat-foi-emergencial.html >.).

Conclui-se que a emergência tem um conceito indeterminado, deve respeitar os princípios da razoabilidade e proporcionalidade. Essa hipótese só pode ser executada na medida em que finde a situação emergencial, sendo o prazo limitado a 180 dias. Persistindo a situação, a solução é formalizar a contratação nos moldes do art. .24 IV lei 8.666/1993 (MONTEBELO, Disponível em: < https://www.passeidireto.com/arquivo/987119/roteiro-adm---marianamontebelo/9 >).

Hely Lopes Meirelles (2016, p. 337) aponta que a motivação, seja na dispensa ou na inexigibilidade de licitação, deve estar presente. O processo em questão deve ser instruído com elementos que evidenciem o caráter emergencial que explique a contratação direta e o seu valor. Ele desenvolve ainda o conteúdo do art. $25 \S 2^{\circ}$ da lei 8666/1993:

Em qualquer dos casos de dispensa ou de inexigibilidade de licitação comprovado o superfaturamento, respondem solidariamente pelo dano causado à Fazenda Pública o fornecedor ou o prestador de serviço e o agente público, sem o prejuízo de outras sanções legais cabíveis.

Mais uma situação excepcional, José dos Santos Carvalho Filho (2016, p. 264) analisa o inciso IX conforme transcrito abaixo:

IX - quando houver possibilidade de comprometimento da segurança nacional, nos casos estabelecidos em decreto do Presidente da República, ouvido o Conselho de Defesa Nacional;

A questão de excepcionalidade do presente dispositivo, no sentido de José dos Santos, é evidente por tratar da segurança nacional, pois é a segurança da própria soberania do país. 
XXVIII - para o fornecimento de bens e serviços, produzidos ou prestados no País, que envolvam, cumulativamente, alta complexidade tecnológica e defesa nacional, mediante parecer de comissão especialmente designada pela autoridade máxima do órgão.

Como observa José dos Santos Carvalho Filho (2016, p. 265), a diferença que esses dois últimos incisos citados é que o XXVIII trata de segurança nacional de forma genérica enquanto que o IX trata dessa segurança de forma específica voltado para a defesa nacional.

\subsubsection{Intervenção no domínio econômico}

VI - quando a União tiver que intervir no domínio econômico para regular preços ou normalizar o abastecimento;

Dispensa exclusiva da União, já que o único Ente legítimo por direito de intervir na ordem econômica. É a hipótese de o Estado agindo como agente normativo e regulador da ordem econômica nos moldes do art. 174 CF. A dispensa está atrelada com a ordem econômica com o fim de regular preços e prestar serviços à coletividade (Oliveira, 2015, p. 70). Atenta-se às hipóteses de contratação direta de entidades do terceiro setor como OS e OSCIPS. O fato de o Estado incrementar entidades como essas há a contratação direta.

\subsubsection{Critério de gêneros perecíveis e obras de arte}

XII - nas compras de hortifrutigranjeiros, pão e outros gêneros perecíveis, no tempo necessário para a realização dos processos licitatórios correspondentes, realizadas diretamente com base no preço do dia;

Enquanto ocorre o procedimento licitatório, a compra pode ser feita de forma direta sem a necessidade de preceder tal procedimento. Isso ocorre por motivo emergencial ao visarem necessidades alimentícias (Carvalho Filho, 2016, p. 265).

Para Rafael Oliveira (2015, p. 77) a contratação direta desse dispositivo depende de três requisitos, conforme a página a seguir: 
... a) gêneros perecíveis; b) provisoriedade: não pode ser habitual a contratação, mas apenas durante o tempo necessário para formalização da licitação; e c) preço do dia: preço praticado no mercado no dia da aquisição, tendo em vista que esses produtos, por suas características, apresentam preços voláteis.

O inciso que trata das obras de arte condiciona a sua aquisição e restauração se compatíveis ou atreladas às finalidades do órgão ou da entidade como se observa na transcrição abaixo:

XV - para a aquisição ou restauração de obras de arte e objetos históricos, de autenticidade certificada, desde que compatíveis ou inerentes às finalidades do órgão ou entidade.

É o talento pessoal de um autor que caracteriza um objeto histórico. Ressalta o preenchimento de duas condições: autenticidade certificada da obra ou do objeto e que os bens a serem adquiridos ou restaurados sejam compatíveis ou inerentes às finalidades do órgão ou entidade (Carvalho Filho, 2016, p. 265).

Enquanto a aquisição a Administração busca atrelar os custos de conservação, já a restauração está de acordo com o art. 13 VII lei 8.666/1993, abrangendo atividade técnica especializada.

\subsubsection{Negócios internacionais}

XIV - para a aquisição de bens ou serviços nos termos de acordo internacional específico aprovado pelo Congresso Nacional, quando as condições ofertadas forem manifestamente vantajosas para o Poder Público;

Dispensa a licitação para a contratação internacional desde que aprovada pelo Congresso Nacional e com ofertas manifestamente vantajosas para o Poder Público.

\subsubsection{Desinteresse na contratação}

V - quando não acudirem interessados à licitação anterior e esta, justificadamente, não puder ser repetida sem prejuízo para a Administração, mantidas, neste caso, todas as condições preestabelecidas; 
Trata-se da licitação deserta em que não há interessados a participar do procedimento de licitação. Se a Administração comprovar que se executar um novo certame haverá prejuízo, pode realizar a contratação direta precedendo a justificativa. Alexandre de Aragão atenta que há a polêmica se “... seria aplicada apenas na inexistência de licitantes, ou se também a ela se subsumiriam os casos em que acenderam licitantes, mas todos foram inabilitados ou desclassificados" (Aragão, 2013, p. 308).

A licitação deserta difere da licitação fracassada. Esta ocorre quando os licitantes têm interesse na licitação, no entanto, estão inabilitados, por não se adequar às normas legais ou, ainda são desclassificados. Normalmente, a licitação fracassada faz haver nova licitação (Carvalho, 2015, p. 488).

VII - quando as propostas apresentadas consignarem preços manifestamente superiores aos praticados no mercado nacional, ou forem incompatíveis com os fixados pelos órgãos oficiais competentes, casos em que, observado o parágrafo único do art. 48 desta Lei e, persistindo a situação, será admitida a adjudicação direta dos bens ou serviços, por valor não superior ao constante do registro de preços, ou dos serviços;

Para José dos Santos Filho (2016, p. 269) a licitação fracassada é classificada como "disparidade de propostas" é a situação em que a dispensa se adequa a uma hipótese que gera prejuízo evidente para o ente público por haver preços incompatíveis com as condições de mercado. Aplica-se o art. $48 \S 3^{\circ}$ para a possibilidade de todas as propostas estarem nos moldes do inciso acima transcrito:

Art. $48 \S 3^{\circ}$ Quando todos os licitantes forem inabilitados ou todas as propostas forem desclassificadas, a administração poderá fixar aos licitantes o prazo de oito dias úteis para a apresentação de nova documentação ou de outras propostas escoimadas das causas referidas neste artigo, facultada, no caso de convite, a redução deste prazo para três dias úteis.

Vale destacar uma ementa relacionada ao tema: "não se dispensa licitação, com fundamento nos incisos V e VII do art. 24 da lei no 8.666/93, caso a licitação fracassada ou deserta tenha sido realizada na modalidade convite" (Orientação Normativa AGU N²12, de 01 de abril de 2009). 
No sentido de José dos Santos Carvalho Filho (2016, p.266), a situação em que “... nenhum particular assuma a postura de desejar a contratação, sequer atendendo à convocação" caracteriza a licitação deserta e a hipótese de "ou então os que tenham apresentado forem provadamente inidôneos" é o fundamento da licitação frustrada.

Assim, como ele (Carvalho Filho, 2016, p. 266) mesmo afirma “... não se consumou o objetivo do procedimento: a seleção da melhor proposta", dessa forma não é situação de desclassificação por não observar o edital. Caberia a Administração realizar nova licitação já que seria violação ao princípio basilar, o da legalidade, conforme explicitado em situação oportuna, se o ente público celebrasse uma contratação direta com alterações significativas das regras anteriores, devendo, assim, haver a permanência das condições básica previamente estabelecidas (Carvalho Filho, 2016, p. 266).

\subsubsection{Entidades sem fins lucrativos}

A Administração tem a prerrogativa de contratar diretamente ainda nas seguintes hipóteses:

XIII - na contratação de instituição brasileira incumbida regimental ou estatutariamente da pesquisa, do ensino ou do desenvolvimento institucional, ou de instituição dedicada à recuperação social do preso, desde que a contratada detenha inquestionável reputação ético-profissional e não tenha fins lucrativos;

O enunciado da PGE esclarece ainda mais o tema:

Enunciado n. ${ }^{\circ} 10$ - PGE: A contratação de qualquer entidade pública ou privada, com fulcro no art. 24, XIII, da Lei n. ${ }^{\circ} 8.666 / 93$, dar-se-á exclusivamente quando o objeto da contratação estiver relacionado com atividades de pesquisa, ensino ou desenvolvimento institucional, para as quais tenha sido criada a entidade contratada, vedada a contratação de pessoa física com base nesse dispositivo, sendo requisitos para a contratação direta: $\left(1 .^{\circ}\right)$ a previsão estatutária dos serviços, $\left(2 .^{\circ}\right)$ a notoriedade de atuação da entidade na área relacionada ao objeto do contrato, reconhecida pelo autorizador ou ordenador de despesa, e (3. ${ }^{\circ}$ ) a experiência demonstrada nessa área de atuação através de atestados de fornecimentos anteriores; no caso de Universidade, a contratação deverá ter sido aprovada pelo respectivo Conselho Universitário ou Conselho Superior de Ensino e Pesquisa. A dispensa de licitação, em qualquer hipótese, deverá ser justificada, na forma do art. 26 da Lei n. ${ }^{\circ}$ 8.666/93. Publicado: DO 18/11/2004 Pág. 09 (grifo nosso). 
Essa hipótese exige que não haja fins lucrativos evidenciando eminente caráter social. José dos Santos Carvalho Filho (2016, p. 267) destaca que esse dispositivo tem sido desviado de seu objetivo, ofendendo o princípio da competitividade quando a Administração contrata com as entidades em questão sem que haja vinculação com os objetivos da instituição.

Assim, ele chama a atenção “... cabe à Administração verificar a presença do vínculo de pertinência (esta não absoluta, mas ao menos relativa) entre os objetivos da instituição e o objeto do contrato ..." (Carvalho Filho, 2016, p. 267).

A súmula 250 do $\mathrm{TCU}^{21}$ ainda ressalta a importância de haver nexo efetivo entre o dispositivo com a natureza e objeto contratado, sendo primordial a compatibilidade com os preços de mercado.

Assemelhe-se a esse dispositivo os abaixo transcritos com inegável teor social e filantrópico e prestação de serviços com as organizações sociais respectivamente:

XX - na contratação de associação de portadores de deficiência física, sem fins lucrativos e de comprovada idoneidade, por órgãos ou entidades da Administração Pública, para a prestação de serviços ou fornecimento de mão-de-obra, desde que o preço contratado seja compatível com o praticado no mercado.

Essa dispensa possui cunho social assim como a anterior. Objetiva fomentar o exercício das atividades. Não há fins lucrativos.

XXIV - para a celebração de contratos de prestação de serviços com as organizações sociais, qualificadas no âmbito das respectivas esferas de governo, para atividades contempladas no contrato de gestão.

As organizações sociais, entidades privadas, atuam prestando serviços públicos não exclusivos do setor público, mas são entidades sem fins lucrativos. Celebram contrato de gestão com a Administração pública. Este “... contrato de gestão é o instrumento firmado entre o Poder Público e a entidade qualificada

\footnotetext{
${ }^{21}$ Súmula 250 TCU: A contratação de instituição sem fins lucrativos, com dispensa de licitação, com fulcro no art. 24, inciso XIII, da Lei n. ${ }^{\circ} 8.666 / 93$, somente é admitida nas hipóteses em que houver nexo efetivo entre o mencionado dispositivo, a natureza da instituição e o objeto contratado, além de comprovada a compatibilidade com os preços de mercado.
} 
como organização social, com vistas à formação de parceria entre as partes para fomento e execução de atividades de interesse público" (Carvalho, 2015, p. 491).

Esse dispositivo foi implementado pela lei 9.648/1998 caracterizando a dispensa de licitação em contratos de prestação de serviços entre Estado e Organizações Sociais e além disso, em contratos que realizem a sua atividadefim, conforme os moldes da parte final do mesmo inciso.

\subsubsection{Complementação do objeto}

XI - na contratação de remanescente de obra, serviço ou fornecimento, em consequência de rescisão contratual, desde que atendida a ordem de classificação da licitação anterior e aceitas as mesmas condições oferecidas pelo licitante vencedor, inclusive quanto ao preço, devidamente corrigido;

Pode haver a dispensa em casos de necessidade de complementação da obra (Carvalho Filho, 2016, p. 270). Deve-se respeitar a ordem de classificação, mantendo as condições da proposta vencedora.

O TCU entendeu que: "é ilegal a contratação, mediante a dispensa de licitação prevista no art. 24, inciso XI da lei 8.666/93, de remanescente de obra com base em condições diversas daquelas que venceram o processo licitatório" (Acórdão 552/2014 - plenário, 12.3.2014).

\subsubsection{Pessoas administrativas}

VIII - para a aquisição, por pessoa jurídica de direito público interno, de bens produzidos ou serviços prestados por órgão ou entidade que integre a Administração Pública e que tenha sido criado para esse fim específico em data anterior à vigência desta Lei, desde que o preço contratado seja compatível com o praticado no mercado;

No entender de José dos Santos Carvalho Filho (2016, p. 270), Rafael Carvalho Oliveira (2015, p. 72), Marcos Juruena Villela Souto (2004, p. $105-$ 106) e Maria Sylvia Zanella Di Pietro (2014, p. 405) a dispensa alcança apenas a hipótese em que a pessoa administrativa é da mesma esfera federativa do ente de direito público, mas não se aplica a pessoas de diferentes órbitas, porém, esse 
pensamento não é unanime (Oliveira, 2015, p. 72). Há quem entenda que a dispensa é aplicável para contratação de entidades administrativas mesmo que integrantes da Administração Pública de outro Ente Federado.

Importante salientar que foi acrescido um novo parágrafo no art. 24 (antigo parágrafo único) que exclui a aplicação do limite de tempo previsto para a possibilidade de dispensa no dispositivo em questão.

XVI - para a impressão dos diários oficiais, de formulários padronizados de uso da administração, e de edições técnicas oficiais, bem como para prestação de serviços de informática a pessoa jurídica de direito público interno, por órgãos ou entidades que integrem a Administração Pública, criados para esse fim específico;

Enquanto no inciso VIII a contratação direta é possível se o ente público administrativo tiver sido criado antes da vigência da lei, as que surgiram posteriormente a esta, competirão com as pessoas privadas.

XXIII - na contratação realizada por empresa pública ou sociedade de economia mista com suas subsidiárias e controladas, para a aquisição ou alienação de bens, prestação ou obtenção de serviços, desde que o preço contratado seja compatível com o praticado no mercado.

Importante destacar o entendimento do TCU (Acórdão 198/2015 Plenário) sobre o tema seguido da súmula 265 do TCU respectivamente:

Para fins de dispensa de licitação com fundamento no art. 24, inciso XXIII, da lei 8.666/93, entende-se por controlada a empresa em que a União, direta ou indiretamente, detenha a maioria do capital social com direito a voto, em analogia ao conceito do art. $165 \$ 5^{\circ}$, inciso II, da Constituição Federal, que baliza a noção de empresa controlada.

A contratação de subsidiárias e controladas com fulcro no art. 24 inciso XXIII, da lei 8.666/1993 somente é admitida nas hipóteses em que houver, simultaneamente, compatibilidade com os preços de mercado e pertinência entre o serviço a ser prestado ou os bens a serem alienados ou adquiridos e o objeto social das mencionadas entidades.

A dispensa explica o fato de existirem empresas subsidiárias das empresas estatais (criadas por autorização de lei) com o objetivo de prestação de serviços públicos atreladas à atividade essencial da entidade que a criou (Carvalho, 2015, p. 491). 


\subsubsection{Locação e compra de imóvel}

X - para a compra ou locação de imóvel destinado ao atendimento das finalidades precípuas da administração, cujas necessidades de instalação e localização condicionem a sua escolha, desde que o preço seja compatível com o valor de mercado, segundo avaliação prévia;

A finalidade desse dispositivo é ter de atender às necessidades do ente público, passando a serem restritas as situações. É requisito essencial o caráter de ser indispensável à Administração.

O Tribunal de Contas da União se pronunciou por uma consulta apresentada pelo Conselho Superior da Justiça do Trabalho, sobre a contratação direta de locação sob medida (operação built to suit). Nesse tipo de locação (sob medida), os contratos estipulados por um prazo determinado extenso de forma que atenda com os requisitos necessários.

Esse Tribunal afirmou que excepcionalmente pode haver a contratação direta de locação sob medida nos fundamentos no dispositivo acima transcrito (Acórdão 1301/2013 - plenário. 29.5.2013).

\subsubsection{Pesquisa e desenvolvimento}

XXI - para a aquisição ou contratação de produto para pesquisa e desenvolvimento, limitada, no caso de obras e serviços de engenharia, a $20 \%$ (vinte por cento) do valor de que trata a alínea "b" do inciso I do caput do art. 23;

O presente dispositivo teve alteração com a Lei 13.243 de 2016 ampliando seu objetivo que deixou de ser exclusivamente pesquisa científica, passando a ser qualquer tipo de produto para pesquisas e desenvolvimento em geral. Como afirma José dos Santos Carvalho Filho (2016, p. 273), tal amplitude se deve ao dispositivo constitucional abaixo:

Art. 218. O Estado promoverá e incentivará o desenvolvimento científico, a pesquisa, a capacitação científica e tecnológica e a inovação. 
Vale ainda destacar o exposto no $\S 4^{\circ}$ do estatuto expõe ser inaplicável ao inciso XXI a vedação de que autor (seja pessoa física ou jurídica) do projeto básico não pode participar seja direta ou indiretamente seja da licitação ou da execução da obra ou serviço e do fornecimento de bens.

Quando o inciso XXI se destinar a obras e serviços de engenharia, será aplicável procedimentos especiais nos moldes do $\S 3^{\circ}$ da lei.

\subsubsection{Energia elétrica}

XXII - na contratação de fornecimento ou suprimento de energia elétrica e gás natural com concessionário, permissionário ou autorizado, segundo as normas da legislação específica;

Nessa hipótese cabe a quem administra escolher o melhor prestador de serviço levando em conta a qualidade da prestação e também o preço cobrado (Carvalho Filho, 2016, p. 274).

\subsubsection{Transferência de tecnologia}

XXV - na contratação realizada por Instituição Científica e Tecnológica - ICT ou por agência de fomento para a transferência de tecnologia e para o licenciamento de direito de uso ou de exploração de criação protegida.

$\mathrm{O}$ presente inciso regulamenta dois artigos constitucionais abaixo transcritos:

Art. 218. O Estado promoverá e incentivará o desenvolvimento científico, a pesquisa, a capacitação científica e tecnológica e a inovação. $\S 1^{\circ}$ A pesquisa científica básica e tecnológica receberá tratamento prioritário do Estado, tendo em vista o bem público e o progresso da ciência, tecnologia e inovação.

$\S 2^{\circ}$ A pesquisa tecnológica voltar-se-á preponderantemente para a solução dos problemas brasileiros e para o desenvolvimento do sistema produtivo nacional e regional.

$\S 3^{\circ} \mathrm{O}$ Estado apoiará a formação de recursos humanos nas áreas de ciência, pesquisa, tecnologia e inovação, inclusive por meio do apoio às atividades de extensão 
tecnológica, e concederá aos que delas se ocupem meios e condições especiais de trabalho.

$\S 4^{\circ}$ A lei apoiará e estimulará as empresas que invistam em pesquisa, criação de tecnologia adequada ao País, formação e aperfeiçoamento de seus recursos humanos e que pratiquem sistemas de remuneração que assegurem ao empregado, desvinculada do salário, participação nos ganhos econômicos resultantes da produtividade de seu trabalho.

$\S 5^{\circ}$ É facultado aos Estados e ao Distrito Federal vincular parcela de sua receita orçamentária a entidades públicas de fomento ao ensino e à pesquisa científica e tecnológica.

$\S 6^{\circ} \mathrm{O}$ Estado, na execução das atividades previstas no caput, estimulará a articulação entre entes, tanto públicos quanto privados, nas diversas esferas de governo.

$\S 7^{\circ} \mathrm{O}$ Estado promoverá e incentivará a atuação no exterior das instituições públicas de ciência, tecnologia e inovação, com vistas à execução das atividades previstas no caput.

Art. 219. O mercado interno integra o patrimônio nacional e será incentivado de modo a viabilizar o desenvolvimento cultural e socioeconômico, o bem-estar da população e a autonomia tecnológica do País, nos termos de lei federal.

Parágrafo único. O Estado estimulará a formação e o fortalecimento da inovação nas empresas, bem como nos demais entes, públicos ou privados, a constituição e a manutenção de parques e polos tecnológicos e de demais ambientes promotores da inovação, a atuação dos inventores independentes e a criação, absorção, difusão e transferência de tecnologia.

A dispensa se justifica a partir da necessidade de fomentar a pesquisa e também a tecnologia, setores os quais possibilitam a contratação direta devido às suas características (Carvalho Filho, 2016, p. 275). A lei no 12.349 de 2010 acrescentou o inciso abaixo transcrito ampliando apenas o conteúdo do XXV.

XXXI - nas contratações visando ao cumprimento do disposto nos arts. $3^{\circ}, 4^{\circ}, 5^{\circ}$ e 20 da Lei no 10.973, de 2 de dezembro de 2004, observados os princípios gerais de contratação dela constantes.

Os artigos da lei 10.973/04 são explicados resumidamente por Rafael Oliveira (2015, p. 84) que analisa: 
... os Entes federados e as respectivas agências de fomento poderão estimular e apoiar a constituição de alianças estratégicas e o desenvolvimento de projetos de cooperação envolvendo empresas nacionais, ICT e organizações de direito privado sem fins lucrativos voltadas para atividades de pesquisa e desenvolvimento, que objetivem a geração de produtos e processos inovadores;

b) as ICTs, na forma do art. $4^{\circ}$ da lei $10.973 / 2004$, após a fixação de prioridades, critérios e requisitos aprovados e divulgados pelo seu máximo, que garantam igualdade de tratamento entre os interessados, poderão, mediante remuneração e por prazo determinado nos termos de contrato ou convênio: I - 'compartilhar seus laboratórios, equipamentos, instrumentos, materiais e demais instalações com microempresas e empresas de pequeno porte em atividades voltadas à inovação tecnológica, para a consecução de atividades de incubação, sem prejuízo de sua atividade finalística;' II 'permitir a utilização de seus laboratórios, equipamentos, instrumentos, materiais e demais instalações existentes em suas próprias dependências por empresas nacionais e organizações de direito privado sem fins lucrativos voltadas para atividades de pesquisa, desde tal permissão não interfira diretamente na sua atividade-fim, nem com ela conflite;

c) a união e as entidades administrativas federais ficam autorizadas a participar minoritariamente do capital de empresa privada de propósito específico que vise ao desenvolvimento de projetos científicos ou tecnológicos para obtenção de produto ou processo inovadores (art. $5^{\circ}$ da lei 10.973/2004);

d) Possibilidade de contratação de empresa, consorcio de empresa e entidades nacionais de direito privado sem fins lucrativos voltadas para atividades de pesquisa, de reconhecida capacitação tecnológica no setor, visando à realização de atividades de pesquisa e desenvolvimento, quem envolvam risco tecnológico, para solução de problema técnico específico ou obtenção de produto ou processo inovador (art. 20 da Lei 10.973/2004).

Dessa forma, esse dispositivo em análise dispensa a licitação para quase tudo que esteja atrelado a pesquisa e inovação tecnológica, é nesse sentido que Joel de Menezes Niebuhr (2013, p. 150) se posiciona e expressa sua posição: "trata-se de absurdo, de normativo abertamente inconstitucional, clientelista, antirrepublicano, que atira ao limbo o princípio da isonomia e a parte inicial do inciso XXI do art. 37 da Constituição Federal”.

\subsubsection{Consórcios públicos e convênios de cooperação}

XXVI - na celebração de contrato de programa com ente da Federação ou com entidade de sua administração indireta, para a prestação de serviços públicos de forma associada nos termos do autorizado em contrato de consórcio público ou em convênio de cooperação. 
A dispensa na presente hipótese se fundamenta pela finalidade de prestar serviços públicos de forma associada, respeitando o consórcio público ou convenio de cooperação. Pela lei 11.107, o contrato de programa consiste na gestão associada de serviços públicos perante entes federativos (Carvalho Filho, 2016, p. 276).

\title{
3.2.15. Navios, embarcações
}

\begin{abstract}
XVIII - nas compras ou contratações de serviços para o abastecimento de navios, embarcações, unidades aéreas ou tropas e seus meios de deslocamento quando em estada eventual de curta duração em portos, aeroportos ou localidades diferentes de suas sedes, por motivo de movimentação operacional ou de adestramento, quando a exiguidade dos prazos legais puder comprometer a normalidade e os propósitos das operações e desde que seu valor não exceda ao limite previsto na alínea "a" do inciso II do art. 23 desta Lei:
\end{abstract}

No dispositivo prevalece que o serviço público deverá ser cumprido sobre o processo de licitação desde que respeitados os pressupostos. Afirma o dispositivo que o valor do contrato tem o limite de até $\mathrm{R} \$ 80.000$. Excedendo esse valor, a dispensa será vedada (Carvalho Filho, 2016, p. 276-277).

\subsubsection{Peças no período de garantia técnica}

XVII - para a aquisição de componentes ou peças de origem nacional ou estrangeira, necessários à manutenção de equipamentos durante o período de garantia técnica, junto ao fornecedor original desses equipamentos, quando tal condição de exclusividade for indispensável para a vigência da garantia;

Ao analisar o dispositivo é possível concluir que no período de garantia técnica, as peças originais de equipamentos podem ser adquiridas pelas fabricantes, revendedores ou representantes comerciais. A contratação direta requer a contratação de garantia. A doutrina diverge sobre a natureza do dispositivo.

Enquanto para José dos Santos Carvalho Filho (2016, p. 277-278) a inviabilidade de licitação é contratual, isto é, o contrato de garantia é acessório ao 
principal, para outros estudiosos do tema a hipótese se adequa à inexigibilidade ${ }^{22}$ por considerarem ser inviável a competição, devendo a Administração adquirir peças apenas do fornecedor.

\title{
3.2.17. Materiais de uso militar
}

\begin{abstract}
XIX - para as compras de material de uso pelas Forças Armadas, com exceção de materiais de uso pessoal e administrativo, quando houver necessidade de manter a padronização requerida pela estrutura de apoio logístico dos meios navais, aéreos e terrestres, mediante parecer de comissão instituída por decreto;
\end{abstract}

Esse inciso também apresenta controvérsia sobre a natureza da contratação direta. Enquanto há quem entenda que se trata de hipótese de inexigibilidade de licitação devendo ser abrangida pelo art. 25, caput, da lei 8666/92, outros entendem que é correto o enquadramento de dispensa. É esse último o entendimento de José dos Santos Carvalho Filho (2016, p. 279).

XXIX - na aquisição de bens e contratação de serviços para atender aos contingentes militares das Forças Singulares brasileiras empregadas em operações de paz no exterior, necessariamente justificadas quanto ao preço e à escolha do fornecedor ou executante $\mathrm{e}$ ratificadas pelo Comandante da Força.

O fundamento desse caso de dispensa objetiva melhor adequação de recursos e ao barateamento de custos (Carvalho Filho, 2016, p. 279).

\subsubsection{Catadores de materiais recicláveis}

XXVII - na contratação da coleta, processamento e comercialização de resíduos sólidos urbanos recicláveis ou reutilizáveis, em áreas com sistema de coleta seletiva de lixo, efetuados por associações ou cooperativas formadas exclusivamente por pessoas físicas de baixa renda reconhecidas pelo poder público como catadores de materiais recicláveis, com o uso de equipamentos compatíveis com as normas técnicas, ambientais e de saúde pública.

\footnotetext{
22 “... a depender do caso concreto, também pode ser tecnicamente mais bem configurado como de inexigibilidade, já que também não haveria a existência de outros fornecedores capazes de atender às condições da garantia. Nele, cessada a garantia, cessada fica a possibilidade de dispensa" (Aragão, 2013, p. 308).
} 
O presente dispositivo trata de uma hipótese da contratação direta de associações ou cooperativas constituídas exclusivamente por pessoas físicas de baixa renda, conhecidas como "catadores de materiais recicláveis". O contrato é firmado com a associação ou com a cooperativa. O objetivo do presente dispositivo é de cunho social, buscando atingir pessoas de baixo poder aquisitivo. Frente a isso, José dos Santos Carvalho Filho (2016, p. 280) acrescenta:

O objetivo da norma da contratação é a coleta, processamento e comercialização de resíduos sólidos recicláveis ou reutilizáveis, em locais onde já se disponha de coleta seletiva de lixo, e nesse mister a lei exige o uso de equipamentos compatíveis com as normas técnicas, ambientais e de saúde pública.

Originada pela Lei 11.445/07 essa dispensa define diretrizes nacionais para o saneamento básico no país e tem por finalidade gerar oportunidade de contratação direta a pessoas de baixo poder aquisitivo, devendo ser respeitadas as normas de saúde pública (Carvalho, 2015, p. 492).

\subsubsection{Agricultura familiar e reforma agrária}

XXX - na contratação de instituição ou organização, pública ou privada, com ou sem fins lucrativos, para a prestação de serviços de assistência técnica e extensão rural no âmbito do Programa Nacional de Assistência Técnica e Extensão Rural na Agricultura Familiar e na Reforma Agrária, instituído por lei federal.

Não é razoável a contratação direta de entidades com fins lucrativos, já que esta deve se submeter à competitividade e deve haver o respeito à impessoalidade (Carvalho Filho, 2016, p. 280).

Essa hipótese está restrita aos serviços de assistência técnica e extensão rural. Não é possível a contratação direta serviço de essência diversa. O contrato firmado nessa hipótese da lei deve ser feito exclusivamente pelo Ministério do Desenvolvimento Agrário e ao INCRA, estando impossibilitadas de uso de tal inciso as demais entidades administrativas (Niebuhr, 2013, p. 148). 


\subsubsection{Produtos estratégicos para o SUS}

XXXII - na contratação em que houver transferência de tecnologia de produtos estratégicos para o Sistema Único de Saúde - SUS, no âmbito da Lei no 8.080, de 19 de setembro de 1990, conforme elencados em ato da direção nacional do SUS, inclusive por ocasião da aquisição destes produtos durante as etapas de absorção tecnológica.

José dos Santos Carvalho Filho (2016, p. 281) destaca que a dispensa atinge as contratações para adquirir os produtos tratados no presente inciso durante as etapas de absorção tecnológica, bastando assim haver o seu início.

A hipótese ressalta a importância da preocupação com o desenvolvimento nacional, fomentando a transferência de tecnologia na área da saúde, com o objetivo de suprir o interesse público (Carvalho, 2015, p. 493).

\subsubsection{Programa de cisternas e acesso à água}

XXXIII - na contratação de entidades privadas sem fins lucrativos, para a implementação de cisternas ou outras tecnologias sociais de acesso à água para consumo humano e produção de alimentos, para beneficiar as famílias rurais de baixa renda atingidas pela seca ou falta regular de água.

No sentido de José dos Santos Carvalho Filho (2016, p. 281), o presente inciso tem eminente cunho social e se explica na emergência da assistência a ser dispensada a essas pessoas. É cabível a licitação na situação em que as entidades tiverem "caráter social e fins lucrativos", já que é a ausência de tais elementos que concretizam o aspecto social e assistencial de dispensa.

\footnotetext{
XXXIV - para a aquisição por pessoa jurídica de direito público interno de insumos estratégicos para a saúde produzidos ou distribuídos por fundação que, regimental ou estatutariamente, tenha por finalidade apoiar órgão da administração pública direta, sua autarquia ou fundação em projetos de ensino, pesquisa, extensão, desenvolvimento institucional, científico e tecnológico e estímulo à inovação, inclusive na gestão administrativa e financeira necessária à execução desses projetos, ou em parcerias que envolvam transferência de tecnologia de produtos estratégicos para o Sistema Único de Saúde - SUS, nos termos do inciso XXXII deste artigo, e que tenha sido criada para esse fim específico em data anterior à vigência desta Lei, desde que o preço contratado seja compatível com o praticado no mercado.
} 
Inciso acrescentado pela Lei 13.204/15 que, em busca de maior desenvolvimento nacional, incluiu a possibilidade de inovação tecnológica e nas parcerias com o SUS para atividades de saúde.

Difere da classificação de licitação dispensável apresentada pelo José dos Santos Carvalho Filho a da Maria Sylvia Zanella Di Pietro que se divide em quatro grupos: de pequeno valor, de situação excepcional, em razão da pessoal e, por fim, em razão do objeto. O inciso XXXIV do Estatuto não entrou em nenhum desses grupos na classificação desta última, entretanto, parte da doutrina afirma que se adéqua em "razão da Pessoa".

A título de comparação com a classificação do José dos Santos já analisada no presente trabalho, cabe a análise da divisão feita pela Maria Sylvia Zanella Di Pietro e pelo Alexandre Aragão através de tabelas com os incisos e de suas respectivas classificações:

Análise do art. 24 lei 8666/1993 na visão da Di Pietro (2014, p. 398-407) DISPENSA DE LICITAÇÃO EM RAZÃO DE:

\begin{tabular}{|c|c|c|c|}
\hline $\begin{array}{l}\text { PEQUENO } \\
\text { VALOR }\end{array}$ & $\begin{array}{c}\text { SITUAÇÃO } \\
\text { EXCEPCIONAL }\end{array}$ & $\begin{array}{c}\text { EM RAZÃO DA } \\
\text { PESSOA }\end{array}$ & $\begin{array}{c}\text { EM RAZÃO DO } \\
\text { OBJETO }\end{array}$ \\
\hline I; II & $\begin{array}{l}\text { III; IV; V; VI; VII; } \\
\text { IX; XI; XIV; } \\
\text { XVIII; XXVII; } \\
\text { XXVIII }\end{array}$ & $\begin{array}{l}\text { VIII; XIII; XVI; } \\
\text { XX; XXII; XXIII; } \\
\text { XXIV; XXVI }\end{array}$ & $\begin{array}{l}\text { X; XII; XV; XVII; } \\
\text { XIX; XXI; XXV; } \\
\text { XXIX; XXX; } \\
\text { XXXI; XXXII; } \\
\text { XXXIII }\end{array}$ \\
\hline
\end{tabular}

Ela acrescenta além dessas hipóteses como situação de dispensa, em razão da pessoa a previsão do art. $1^{\text {o }}$ - A da lei 8958/1994 ${ }^{23}$.

Análise do art. 24 lei 8.666/1993 na perspectiva do Alexandre Aragão (2013, p. 307-310) muito semelhante à Di Pietro com sutis diferenças como se observa no quadro a seguir - DISPENSA DE LICITAÇÃO EM RAZÃO DE:

\footnotetext{
23 Art. 1o-A. A Financiadora de Estudos e Projetos - FINEP, como secretaria executiva do Fundo Nacional de Desenvolvimento Científico e Tecnológico - FNDCT, o Conselho Nacional de Desenvolvimento Científico e Tecnológico - $\mathrm{CNPq}$, as agências financeiras oficiais de fomento e empresas públicas ou sociedades de economia mista, suas subsidiárias ou controladas, poderão celebrar convênios e contratos, nos termos do inciso XIII do caput do art. 24 da Lei $n^{\circ}$ 8.666, de 21 de junho de 1993, por prazo determinado, com as fundações de apoio, com finalidade de dar apoio às IFES e às demais ICTs, inclusive na gestão administrativa e financeira dos projetos mencionados no caput do art. 1o, com a anuência expressa das instituições apoiadas.
} 


\begin{tabular}{|c|c|c|c|}
\hline VALOR & $\begin{array}{c}\text { SITUAÇÕES } \\
\text { EXCEPCIONAIS }\end{array}$ & ОВJETO & PESSOA \\
\hline I; II & $\begin{array}{l}\text { III; IV; V; VI; VII; } \\
\text { IX; XI com art. } 64 \\
\text { §2; XIV; XVIII E } \\
\text { XXXII }\end{array}$ & $\begin{array}{l}\text { X; XII; XV; XVII; } \\
\text { XIX; XXI; XXV; } \\
\text { XXVI; XXVII; } \\
\text { XXVIII; XIX; } \\
\text { XXX }\end{array}$ & $\begin{array}{l}\text { VIII; XIII; XVI; } \\
\text { XX; XXII; XXIV; } \\
\text { XXXI. }\end{array}$ \\
\hline
\end{tabular}

Assim, segundo a concepção de Gustavo Binenbojm (2008, p. 341) no que se refere à contratação direta, deve haver uma análise do caso concreto:

Licitar nestes casos dispensáveis é agir contra esse prévio juízo legislativo e exige um ônus de justificação bastante robusto e específico para o caso concreto, eis que a melhor proposta, segundo a lei será alcançada pelo ente contratante mediante contratação direta.

É possível observar que, regra geral, em casos em que é permitida a dispensa, essa será executada de acordo com seus requisitos, mesmo possuindo ampla faculdade e juízo de discricionariedade. 


\section{CAPÍTULO 4: CONTRATAÇÃO DIRETA: INEXIGIBILIDADE E LICITAÇÃO DISPENSADA}

\subsection{Inexigibilidade}

Finda-se a análise de todas as conjecturas de licitação dispensável, situações em que pode haver a licitação, nada obstante deixa de ser conveniente a sua realização. Sucede-se o exame das hipóteses de inexigibilidade, outro modo de contratação direta, sem licitação.

Como se percebe, esta última se embasa na inviabilidade da competição propriamente dita. Enquanto a dispensa apresenta um rol taxativo, a inexigibilidade porta um rol meramente exemplificativo, podendo exceder às expostas no art. 25 do estatuto bastando haver a adequação do caso concreto.

Gustavo Binenbojm (2008, p. 343) ao tratar da inviolabilidade de competição faz referência a um conceito relativo, de acordo com o caso concreto, nos moldes a seguir:

A inviabilidade de competição é conceito relativo e contextual, que se verifica diante das circunstâncias de cada caso concreto, quando a busca da solução mais vantajosa para a Administração não se mostrar possível através do procedimento licitatório. Desse modo, há consenso no sentido de que a enumeração do art. 25 é exemplificativa.

Para ele, essa inviabilidade de competição não apresenta um conceito absoluto e geral, carecendo da análise do caso concreto (Aragão, 2013, p. 310). Reitera o objetivo da vantajosidade, devendo espreitar maior vantagem à Administração Pública. Já Marcos Juruena Villela Souto (1998, p. 141-142) atrela a inexigibilidade à inviabilidade de competição e impossibilidade de comparações como se observa abaixo:

\footnotetext{
A licitação inexigível ocorre nas hipóteses em que a competição é inviável ante a inexistência de concorrentes ou da impossibilidade de serem comparados itens heterogêneos; assim, por exemplo, não se compara uma letra de música de Tom Jobim com uma de Vinicius de Moraes, ou um parecer de Celso Ribeira Bastos com uma de Celso Antônio Bandeira de Mello. Não havendo como se instaurar a competição, não tem sentido o procedimento licitatório. $\mathrm{O}$ bem singular não pode ser oferecido por mais de uma pessoa, logo, não há como viabilizar confronto.
} 
A inexigibilidade de licitação intercorre na impossibilidade jurídica de competir entre os contratantes nas mais diversas situações, seja pela natureza específica do negócio ou pelos objetivos sociais visados pela administração (Santos, 2012, p. 526 e Meirelles, 2016, p. 333-334).

Cabe ponderar cada uma das hipóteses previstas expressamente na lei 8.666/1993. O caput, preliminar aos incisos dos incisos assim dispõe:

Art. 25. É inexigível a licitação quando houver inviabilidade de competição, em especial:

\subsubsection{Fornecedor exclusivo}

I - para aquisição de materiais, equipamentos, ou gêneros que só possam ser fornecidos por produtor, empresa ou representante comercial exclusivo, vedada a preferência de marca, devendo a comprovação de exclusividade ser feita através de atestado fornecido pelo órgão de registro do comércio do local em que se realizaria a licitação ou a obra ou o serviço, pelo Sindicato, Federação ou Confederação Patronal, ou, ainda, pelas entidades equivalentes;

Esse é o caso de apenas uma empresa prover um produto específico, não havendo outra que possa concorrer (Santos, 2012, p. 526). José dos Santos Carvalho Filho (2016, p. 283) analisa dois tipos de exclusividade: relativa e absoluta.

Para ele (Carvalho Filho, 2016, p. 283), a absoluta consiste na existência de um produtor ou representante comercial exclusivo no país e a relativa consiste quando "havendo fora da praça mais de um fornecedor ou representante comercial, poderá ser realizada a licitação, se a Administração tiver interesse em comparar várias propostas".

Inclui ainda que a exclusividade tem que ser conferida. Esta se promove por um atestado fornecido pelo órgão de registro de comércio do local em que transcorreria a licitação, a obra ou o serviço. Pode ocorrer por sindicatos, federação ou confederação patronal ou entidade equivalentes (Carvalho Filho, 2016, p. 283).

Há que se observar uma tendência de que os órgãos competentes por contratar estão obrigados a apurar a veracidade do atestado de exclusividade 
fornecido (Orientação Normativa AGU Normativa AGU N¹6, de 01 Abril de 2009).

Finalmente, José dos Santos Carvalho Filho (2016, p. 283) testifica a possibilidade de escolher uma marca exclusivamente em três hipóteses: "1 continuidade da utilização de marca já adotada no órgão"; "2 - para a utilização de nova marca conveniente; e"; "3 - para o fim de padronização de marca no serviço público, todas evidentemente justificadas pela necessidade da administração".

\subsubsection{Serviços técnicos especializados}

II - para a contratação de serviços técnicos enumerados no art. 13 desta Lei, de natureza singular, com profissionais ou empresas de notória especialização, vedada a inexigibilidade para serviços de publicidade e divulgação;

Nesta circunstância são três os requisitos que devem estar presentes cumulativamente, são eles: serviço técnico, serviço singular e notória especialização do contratado. A inviabilidade se apoia nessa presunção pela ausência de critério objetivo para selecionar a asserção mais vantajosa da contratação. A lei ao tratar do corrente inciso elucida o que é "notória especialização" no $\S 1^{\circ}$ do mesmo dispositivo conforme transcrito abaixo:

$\S 10$ Considera-se de notória especialização o profissional ou empresa cujo conceito no campo de sua especialidade, decorrente de desempenho anterior, estudos, experiências, publicações, organização, aparelhamento, equipe técnica, ou de outros requisitos relacionados com suas atividades, permita inferir que o seu trabalho é essencial e indiscutivelmente o mais adequado à plena satisfação do objeto do contrato.

A presente hipótese de "notória especialização não justificará a contratação direta quando for desnecessária para a satisfação da necessidade estatal" (Justen Filho, 2012, p. 496).

Quanto ao $\$ 1^{\circ}$, José dos Santos (2012, p. 529 e Aragão, 2013, p. 311) sustenta ser possível mais de uma especialização notória no mercado. No mesmo sentido pensa Mauro Roberto Gomes de Mattos (2002, p. 508). A lei acrescenta o 
requisito de "natureza singular". Dessa forma, enquadra-se nessa situação uma definição de serviços singulares (Grau, 1999, p. 70):

\begin{abstract}
Singulares são os serviços que apenas podem ser prestados, de certa maneira e com determinado grau de confiabilidade, por um determinado profissional ou empresa. Por isso mesmo é que a singularidade do serviço está contida no bojo da notória especialização.
\end{abstract}

Conclui-se que deve ser singular a característica do objeto, havendo um caráter personalíssimo. No entanto, a presente definição ainda é tema de divergência para os estudiosos do tema, já que há quem restrinja a definição de singularidade ao profissional e não com o objeto em questão (FRIAS, Disponível em:<http://mpc.ms.gov.br/uploads/upload/1321895469_ARTIGO_Osmar_PDF.p df $>$ ).

É oportuno sobrelevar a contratação direta de advogados. Os requisitos do STF ao julgar o tema são: “(a) procedimento administrativo prévio; (b) notória especialização do profissional; (c) singularidade do serviço; (d) inadequação do serviço pelos integrantes da entidade pública; (e) preço compatível com o mercado" (Carvalho Filho, 2016, p. 285).

Isto posto, agrega-se que cumpre aos Tribunais de Contas, ao Poder Judiciário e ao Ministério Público assegurar os casos de inexigibilidade em se tratando de notória especialização, cada um adequado na sua respectiva atuação. O TCU (acórdão 3795/2013 - segunda Câmara) entende no seguinte sentido:

\footnotetext{
A regra para a contratação de serviços advocatícios é a licitação, sendo a inexigibilidade 'exceção', a qual deve ser precedida, obrigatoriamente, da comprovação da inviabilidade fática ou jurídica de competição, da singularidade do objeto e da notoriedade do contratado.
}

Quanto à cognição do STF e do STJ frente ao conteúdo, realizou-se uma pesquisa com a análise de 10 acórdãos que empreenderam a discussão acerca da legalidade da contratação. Significativa parcela destas contratações foram executadas sob a notória especialização do profissional acordado e quatro apenas fundamentados pela singularidade do objeto. No entanto, o art. 25 da lei 8.666/1993 é o dispositivo base de tais contratações. 
Em um acórdão do STF foi inquirida a singularidade do objeto considerado como exclusivo para ser enquadrado na hipótese de inexigibilidade. $\mathrm{Na}$ ótica do STF e do STJ a contratação deve velar o serviço cuja singularidade seja considerável para a Administração a fim de que seja estabelecida a inexigibilidade de licitação.

O STJ em oportunidade de definir a singularidade declarou a natureza unívoca do serviço por ser este "único, devido à sua complexidade e relevância". Consequentemente, é viável observar que não se discorre de matéria controversa no STF e no STJ que em prognose de haver singularidade é hipótese de contratação direta, devendo haver o preenchimento dos requisitos para designar a inviabilidade de contratação (Alvarenga, 2016, p. 120-128).

Assim, com base na doutrina e jurisprudência predominantes, a contratação direta de profissionais ou empresas advocatícias só pode ser efetivada se houver notória especialização e com seus objetos singulares.

Afinal, segue abaixo o dispositivo que versa sobre os serviços técnicos profissionais especializados:

Seção IV: Dos Serviços Técnicos Profissionais Especializados

Art. 13. Para os fins desta Lei, consideram-se serviços técnicos profissionais especializados os trabalhos relativos a:

I - estudos técnicos, planejamentos e projetos básicos ou executivos;

II - pareceres, perícias e avaliações em geral;

III - assessorias ou consultorias técnicas e auditorias financeiras ou tributárias; (Redação dada pela Lei $\mathrm{n}^{\circ} 8.883$, de 1994)

IV - fiscalização, supervisão ou gerenciamento de obras ou serviços;

V - patrocínio ou defesa de causas judiciais ou administrativas;

VI - treinamento e aperfeiçoamento de pessoal;

VII - restauração de obras de arte e bens de valor histórico.

VIII - (Vetado). (Incluído pela Lei no 8.883, de 1994)

$\S 1$ 1o Ressalvados os casos de inexigibilidade de licitação, os contratos para a prestação de serviços técnicos profissionais especializados deverão, preferencialmente, ser celebrados mediante a realização de concurso, com estipulação prévia de prêmio ou remuneração.

$\S 2$ o Aos serviços técnicos previstos neste artigo aplica-se, no que couber, o disposto no art. 111 desta Lei.

§ 3o A empresa de prestação de serviços técnicos especializados que apresente relação de integrantes de seu corpo técnico em procedimento licitatório ou como elemento de 
justificação de dispensa ou inexigibilidade de licitação, ficará obrigada a garantir que os referidos integrantes realizem pessoal e diretamente os serviços objeto do contrato.

Como se percebe, o art. 13 abrange um rol exemplificativo dos serviços técnicos profissionais especializados circundando a aplicação de conhecimento técnico-científico, todavia “... se caracterizam pela indispensável atuação de um ser humano, que promove a criação de uma utilidade por meio de sua capacidade física ou intelectual" (Justen Filho, 2012, p. 494).

Celso Antônio Bandeira de Mello (2012, p.563) expõe sobre o presente artigo:

Em suma: a singularidade é relevante e um serviço deve ser havido como singular quando nele tem de inferir, como requisito de satisfatório atendimento da necessidade administrativa, um componente criativo de seu autor, envolvendo o estilo, o traço, a engenhosidade, a especial habilidade, a contribuição intelectual, artística ou a argúcia de quem o executa, atributos, estes, que são precisamente os que a Administração reputa convenientes e necessita para a satisfação do interesse público em causa.

Rafael Oliveira (2015, p. 44) elucida sobre as empresas de prestação de serviços técnicos especializados que estão obrigadas a realizar diretamente o serviço, nesse sentido:

A empresa de prestação de serviços técnicos especializados, que apresente relação de integrantes de seu corpo técnico em procedimento licitatório ou como elemento de justificação da contratação direta, ficará obrigado a garantir que os referidos integrantes realizem pessoal e diretamente serviços objeto do contrato (art. $13 \S 3^{\circ}$ a lei 8.666/1993).

A par dos presentes conceitos evidenciados, é razoável concluir que Celso Antônio aclara que a "singularidade" a partir de "atributos singulares" têm como pressupostos serem não apenas convenientes, mas também necessários para o interesse público. Já Rafael Oliveira (2015 p. 91), ao tanger a "empresa de prestação de serviços técnicos especializados" atrela a esta certa realização pessoal e direta sendo atributo da inexigibilidade. 


\subsubsection{Atividades artísticas}

III - para contratação de profissional de qualquer setor artístico, diretamente ou através de empresário exclusivo, desde que consagrado pela crítica especializada ou pela opinião pública.

"A arte se caracteriza por um duplo subjetivismo, que dificulta intensamente a sua avaliação" proposição atribuída ao Marçal (2012, p. 497) sobre o subjetivismo do artista e o da plateia, resultando no julgamento do ator. Este, por sua vez, deriva, em seu parecer, de "processos psicológicos inconscientes" (Justen Filho, 2012, p. 497).

A tendência do TCU (acórdão 7.770/2015 - Primeira Câmara) se enquadra no seguinte sentido:

Para a contratação direta de profissional do setor artístico (art. 25, inciso III, da Lei 8.666/93) por meio de intermediário, exige-se a comprovação da existência de contrato de exclusividade entre a empresa ou o empresário contratado e o artista, não sendo suficiente documento que confere exclusividade apenas para o dia da apresentação e rescrita à localidade do evento.

Para José dos Santos Carvalho Filho (2016, p. 284) o presente inciso se explica pela sua natureza, já que ele afirma que "a arte é personalíssima, não sendo podendo sujeitar a fatores objetivos de avaliação”. Destarte, será inexigível a licitação. Nesse sentido também assenta Alexandre Aragão que afirma: “... menos sujeita a critérios objetivos" (Aragão, 2013, p. 312). Ao seu entender a "consagração" é um termo relativo, podendo variar a depender do tempo e do espaço. Para ele, o legislador buscou sobrelevar o artista e sua produção (Carvalho Filho, 2016, p. 284).

Sobre o tema, vale observar uma ementa do STJ e dois enunciados da PGE/RJ que tratam do tema, respectivamente:

"EMENTA: CRIMINAL. RESP. CRIME COMETIDO POR PREFEITO. COMPETÊNCIA ORIGINÁRIA DO TRIBUNAL DE JUSTIÇA. REJEIÇÃO DA DENÚNCIA. CONTRATAÇÃO DE ADVOGADO E DE EMPRESA DE AUDITORIA PELO MUNICÍPIO. INEXIGIBILIDADE DE LICITAÇÃO. INVIABILIDADE DE COMPETIÇÃO NÃO DEMONSTRADA. RECURSO 
CONHECIDO E PROVIDO. I - A inviolabilidade de competição, da qual decorre a inexigibilidade de licitação, deve ficar adequadamente demonstrada, o que não ocorreu in casu. II - Não prevalece o acórdão que rejeita a denúncia sem demonstrar o cumprimento dos requisitos legais pela Administração Pública para a contratação sem licitação, limitando-se a fazer considerações acerca de sua possibilidade. III - Deve ser cassado o acórdão recorrido para que outro seja proferido, com a devida fundamentação, se for o caso da inviolabilidade de competição nas contratações efetuadas pela Administração Pública quando da contratação dos serviços. IV - Recurso conhecido e provido, nos termos do voto do Relator" (STJ - Resp 704108 / MG - Relator: Ministro GILSON DIPP (1111) - Órgão Julgador: Quinta Turma - Publicação: DJ 16.05.2005 p.402).

O STJ acentua que os fatores de inexigibilidade devem estar restritos aos pressupostos previstos em lei, verificando o princípio basilar da Administração Pública: o da legalidade. Assim, os requisitos não são absolutos nem gerais, deve-se analisar o caso concreto para que a inexigibilidade seja cabível. Observase no Enunciado da PGE/RJ abaixo um exemplo de inexigibilidade aplicável ao caso concreto constatando os princípios da razoabilidade e da proporcionalidade como in supra:

Enunciado n. ${ }^{\circ}$ 23-PGE: Contrata-se por inexigibilidade de licitação com fundamento no art. 25, caput, da lei $\mathrm{n}^{\circ} 8.666 / 93$, conferencistas para ministrar cursos para treinamento e aperfeiçoamento de pessoal, ou a inscrição em cursos abertos, desde que caracterizada a singularidade do objeto e verificada a adequação do preço aos parâmetros de mercado, além dos demais requisitos previstos no art. 26, § único, da Lei n. ${ }^{\circ} 8.666 / 93$.

Publicado: DO 30/09/2009 Pág. 13

Enunciado no 26 - PGE: "É obrigatória a justificativa de preço nas hipóteses de inexigibilidade de licitação, que poderá ser realizada mediante a comparação da proposta apresentada com os preços de mercado praticados pela futura Contratada em outros contratos cujo objeto seja semelhante ao que se pretende contratar (Pareceres FAG no 22/2005 e 08/2008, ARSJ, SMG no 27/2009 e JLFOL n ${ }^{\circ}$ 06/2000. Publicado: DO I, de 18/10/2011. p. 16).

Então, frisa-se a conveniência da motivação, aplicável não só na inexigibilidade, mas também nas ocorrências de dispensa. Marçal Justen Filho (2012, p. 492) sistematiza determinadas possibilidades que podem gerar a inviabilidade de licitação. Certifica que "a dificuldade é causada pela complexidade do mundo real, cuja riqueza é impossível de ser delimitada por 
meio de regras legais". Por conseguinte, seu esquema apresenta o seguinte padrão:

INVIABILIDADE DE COMPETIÇÃO:

\begin{tabular}{|c|}
\hline Por ausência de pluralidade de alternativas \\
\hline Por ausência de "mercado concorrencial" \\
\hline Por impossibilidade de julgamento objetivo \\
\hline Por ausência de definição objetiva da prestação \\
\hline
\end{tabular}

Deste modo, a inviabilidade de competição pode ser originada da carência de pluralidade de alternativas de contratação para a Administração Pública. Marçal Justen Filho (2012, p. 492) agrega que havendo um único particular que preencha os requisitos de executar as prestações, a licitação será inviável.

Quanto a ausência de "mercado concorrencial", esta hipótese se amolda no contexto de inexistência de ofertas permanentes de contratação. Os particulares que possuem condições de executar a determinada prestação não competem entre si. Marçal adita que não há competição direta e frontal. Ele exemplifica com uma contratação de um cirurgião altamente especializado, ainda afirma "profissionais de grande especialização somente se dispõem a serem contratados se o interessado a eles se dirigir diretamente" (Justen Filho, 2012, p. 492).

$\mathrm{Na}$ suposta "impossibilidade de julgamento objetivo" há um intrínseco caráter personalíssimo da atuação do particular impedindo tal julgamento. Nesse modelo, Marçal Justen Filho (2012, p. 492) ressalta que "essa incerteza deriva basicamente da natureza subjetiva da avaliação, pois a natureza da prestação envolve fatores intelectuais, artísticos, criativos e assim por diante”.

Ademais Marcos Juruena Villela Souto (1998, p. 158) deslinda importante aspecto em comum das duas formas de contratação direta acima explicadas quando declara que "a justificação da situação de dispensa e inexigibilidade de licitação é obrigatória, exigindo-se a motivação do ato, excetuando as referentes à dispensa em razão do valor do objeto, que (se confirmada a estimativa) por si só se justificam". 
O autor (Souto, 1998, p. 160) inclui o que deve estar em um processo:

- caracterização da situação excepcional que justifique a dispensa, aí envolvidos os aspectos fáticos, estes últimos atestados por profissional da área;

- indicação do dispositivo legal aplicável;

- razão da escolha do contratante;

- justificativa do preço (salvo se a contratação direta for em razão do pequeno valor.

São os elementos indispensáveis ao controle, tanto hierárquico (dentro da própria Administração) como externo, legislativo (via Tribunal de Contas) ou judicial (via ação popular).

Nessa medida, observa-se que havendo a inexigibilidade pela razão do presente inciso, ainda que apresentados diferentes requisitos para a legitimação da inviabilidade ora em análise por diferentes estudiosos do tema, deve haver submissão aos pressupostos legais para a sua efetividade.

\subsection{Licitação Dispensada}

Há hipóteses em que a dispensa é vinculada, isto é, estabelecida na lei de forma taxativa. É o que sucede com a licitação dispensada, referente às possibilidades de alienação de bens imóveis ou móveis da Administração Pública (Garcia, 2010, p. 44). Vale a análise do dispositivo abaixo transcrito seguido de importantes observações:

Art. 17. A alienação de bens da Administração Pública, subordinada à existência de interesse público devidamente justificado, será precedida de avaliação e obedecerá às seguintes normas:

É patente no caput do dispositivo o princípio da indisponibilidade do interesse público. Deve haver motivação e avaliação prévia do bem. Rafael Oliveira (2015, p.63) certifica que:

segundo a doutrina tradicional, a licitação dispensada apresenta três características básicas: a) rol taxativo; b) objeto do contrato é restrito: alienação de bens; e c) ausência de discricionariedade do administrador, pois o próprio legislador dispensou previamente a licitação. 
Tanto Rafael Oliveira (2015, p. 63) quanto Marçal Justen Filho (2002, p. 235) entendem que essa autorização não vincula o administrador, que possui discricionariedade, obtendo a faculdade de optar pela licitação ou não. Assim, na ótica de ambos a licitação dispensada retira a exigência de licitação, não transcorrendo esse contexto em outras exigências da lei, em se tratando de alienação de bens das entidades da Administração.

Cabe analisar o artigo em questão:

I - quando imóveis, dependerá de autorização legislativa para órgãos da administração direta e entidades autárquicas e fundacionais, e, para todos, inclusive as entidades paraestatais, dependerá de avaliação prévia e de licitação na modalidade de concorrência, dispensada esta nos seguintes casos:

Este inciso trata de bens imóveis. Regra geral, para alienar os bens imóveis deve haver a precedência de autorização legislativa. Destarte, a especificação é haver a licitação na modalidade de concorrência. A exceção é a circunstância em que a licitação é dispensada, em concordância o caso em questão.

A alienação trata de transferir o domínio de bens da Administração Pública em prol do interesse público devendo sempre ser acompanhada de uma prévia avaliação, como dispõe o presente inciso (Garcia, 2010, p. 17).
a) dação em pagamento;
b) doação, permitida exclusivamente para outro órgão ou entidade da administração pública, de qualquer esfera de governo, ressalvado o disposto nas alíneas $\mathrm{f}, \mathrm{h}$ e i;
c) permuta, por outro imóvel que atenda aos requisitos constantes do inciso X do art. 24 desta Lei;

É elementar que o bem a ser recebido pela Administração seja imprescindível. Marcos Juruena Villela Souto (1998, p. 116) reconhece:

\footnotetext{
A administração para fazer permuta, deve receber algum bem de localização indispensável para o atendimento de seus interesses e finalidades (o que é analisado discricionariamente).

d) investidura;

e) venda a outro órgão ou entidade da administração pública, de qualquer esfera de governo;
} 
f) alienação gratuita ou onerosa, aforamento, concessão de direito real de uso, locação ou permissão de uso de bens imóveis residenciais construídos, destinados ou efetivamente utilizados no âmbito de programas habitacionais ou de regularização fundiária de interesse social desenvolvidos por órgãos ou entidades da administração pública;

g) procedimentos de regularização fundiária de que trata o art. 29 da Lei no 6.383, de 7 de dezembro de 1976;

g) procedimentos de legitimação de posse de que trata o art. 29 da Lei no 6.383, de 7 de dezembro de 1976, mediante iniciativa e deliberação dos órgãos da Administração Pública em cuja competência legal inclua-se tal atribuição;

h) alienação gratuita ou onerosa, aforamento, concessão de direito real de uso, locação ou permissão de uso de bens imóveis de uso comercial de âmbito local com área de até $250 \mathrm{~m}^{2}$ (duzentos e cinquenta metros quadrados) e inseridos no âmbito de programas de regularização fundiária de interesse social desenvolvidos por órgãos ou entidades da administração pública;)

i) alienação e concessão de direito real de uso, gratuita ou onerosa, de terras públicas rurais da União na Amazônia Legal onde incidam ocupações até o limite de 15 (quinze) módulos fiscais ou 1.500ha (mil e quinhentos hectares), para fins de regularização fundiária, atendidos os requisitos legais;

II - quando móveis, dependerá de avaliação prévia e de licitação, dispensada esta nos seguintes casos:

a) doação, permitida exclusivamente para fins e uso de interesse social, após avaliação de sua oportunidade e conveniência socioeconômica, relativamente à escolha de outra forma de alienação;

b) permuta, permitida exclusivamente entre órgãos ou entidades da Administração Pública;

c) venda de ações, que poderão ser negociadas em bolsa, observada a legislação específica;

Marcos Juruena Villela Souto $(1998$, p. 117) certifica que quanto à venda de ações:

... nas alienações decorrentes do Programa Nacional de Desestatização, que tem levado à privatização de empresas estatais. Frise-se que se da venda das ações resultar a perda do controle acionário, modificando a natureza jurídica da empresa estatal com criação legalmente prevista, há que se obter previa autorização legislativa (genérica ou específica).

d) venda de títulos, na forma da legislação pertinente;

e) venda de bens produzidos ou comercializados por órgãos ou entidades da Administração Pública, em virtude de suas finalidades;

f) venda de materiais e equipamentos para outros órgãos ou entidades da Administração Pública, sem utilização previsível por quem deles dispõe.

Transcritos os dispositivos legais referentes à alienação de bens móveis e imóveis da Administração Pública, o $\S 4^{\circ}$ do artigo 17 excepciona a regra de dispensa de licitação para a doação de bens públicos, móveis ou imóveis. Conforme Maria Sylvia Zanella Di Pietro (2014, p. 397) expõe: 
... obriga a realização de licitação quando se tratar de doação com encargo, hipótese em que 'de seu instrumento convocatório constarão, obrigatoriamente, os encargos, o prazo de seu cumprimento e cláusula de reversão, sob pena de nulidade do ato'. Porém, dispensa a licitação no caso de interesse público devidamente justificado.

Nesses moldes, na hipótese de doação com encargo, se houver a motivação confirmando o interesse público, a contratação direta será adequada, comprovando a importância dos princípios da razoabilidade e da proporcionalidade na análise dos casos concretos. Abaixo cabe a averiguação de um quadro comparativo dos incidentes de dispensa e de inexigibilidade a fim de maior clareza do tema.

Resumo esquemático da dispensa e da inexigibilidade com as ideias principais dos institutos (Esquematizado de forma parecida - Carvalho, 2015, p. 495):

\begin{tabular}{|l|l|}
\hline \multicolumn{1}{|c|}{ INEXIGIBILIDADE - ART. 25 } & \multicolumn{1}{c|}{ DISPENSA - ART.17 E 24 } \\
\hline - competição impossível = licitação inexigível & - competição é possível, mas a \\
- hipóteses dispostas na lei são exemplificativas & $\begin{array}{l}\text { lei diz que é dispensada a } \\
\text { - vedada a inexigibilidação. } \\
\text { serviços de divulgação e serviços de publicidade } \\
\text { - hipóteses taxativas/ exaustivas }\end{array}$ \\
\hline
\end{tabular}

Pelo art. 17 em que a licitação é dispensada, o administrador não emite nenhum juízo de valor. A contratação direta é imperativa nessa hipótese, é um ato vinculado, não apresenta discricionariedade.

Rafael Oliveira (2015, p. 64) resume as hipóteses da licitação dispensada da seguinte forma:

a) dação em pagamento; b) doação; c) permuta; d) investidura; e) venda para outros órgãos ou entidades administrativas; f) programas habitacionais; g) vendas de ações, que poderão ser comercializadas em bolsa; $h$ ) venda de bens quando a entidade administrativa possui essa finalidade; i) procedimentos de legitimação de posse de que trata o art. 29 da lei 6.383, e 07.12.1976, j) alienação gratuita ou onerosa, aforamento, concessão de direito real de uso, locação ou permissão de uso de bens imóveis de uso comercial de âmbito local com área de até $250 \mathrm{~m}^{2}$. 
A dação em pagamento consiste na possibilidade de o credor receber prestação diferente daquela que fora compactuada. O Art. $19^{24}$ do estatuto dispõe que determinados bens imóveis da Administração Pública que tenham sido adquiridos por procedimentos judiciais ou por dação em pagamento, tem a possibilidade de ser alienados por ato da autoridade competente, respeitados determinados requisitos, são eles: a avaliação dos bens alienáveis; a comprovação da necessidade ou utilidade da alienação; e a adoção do procedimento licitatório, sob a modalidade de concorrência ou leilão.

Quanto à doação de bens imóveis, o $\S 1^{\circ}$ do art. 17 dispõe que, finalizadas as razões que explicaram sua doação, reverterão ao patrimônio da pessoa jurídica doadora, proibida sua alienação pelo beneficiário. Deve-se atentar à exigência de demonstração de interesse público em qualquer ato de alienação. Acrescenta-se conforme o inciso I B do mesmo artigo que a doação só pode ser efetivada para outro órgão ou entidade da Administração Pública. Para Maria Sylvia Zanella Di Pietro (2014, p. 397), trata-se de uma presunção de uma hipótese específica de doação condicionada: “... ela é feita para que o donatário utilize o imóvel para fins de interesse público; se deixar de haver essa utilização, o bem volta para o patrimônio do doador".

O STF em interpretação conforme à Constituição do art. 17 I, "b"; "c"; II "b" e $\S 1^{\circ}$ esclareceu que a vedação se aplica na esfera da União Federal (ADI $927 \mathrm{MC} / \mathrm{RS})$.

Os Entes Federativos, com suas respectivas autonomias políticas, na autoadministração de seus bens e serviços, têm competência para legislar sobre a gestão de seus bens, incluindo as hipóteses de licitação dispensada.

\footnotetext{
${ }^{24}$ Art. 19. Os bens imóveis da Administração Pública, cuja aquisição haja derivado de procedimentos judiciais ou de dação em pagamento, poderão ser alienados por ato da autoridade competente, observadas as seguintes regras:

I - avaliação dos bens alienáveis;

II - comprovação da necessidade ou utilidade da alienação;

III - adoção do procedimento licitatório, sob a modalidade de concorrência ou leilão.
} 


\section{CONCLUSÃO}

$\mathrm{O}$ intuito do presente trabalho científico foi de inicialmente apresentar aspectos gerais da licitação através de visões e óticas diferenciadas. A partir disso, esclareceu-se conceitos básicos através de apurações doutrinárias, jurisprudenciais, legais e constitucionais. Nesse diapasão, superou-se as definições nas suas diversas elucidações de formulações indispensáveis para a compreensão do instituto em análise como seus objetivos, objetos, fins, sujeitos e pressupostos.

Como não poderia se abster, a lei 8.666/1993 ostentou um balanço do procedimento licitatório a partir da definição de suas modalidades, esclarecendo suas peculiaridades como as conjecturas, conceitos, valores e um breve processamento de cada uma delas. Concluiu-se que a depender do objeto a ser licitado é cabível uma ou algumas modalidades que são obrigatórias na realização desse procedimento executado pela Administração Pública.

Há de se intentar que todas essas considerações são fundamentais para compreender a licitação, procedimento vinculado previsto constitucionalmente, sucedendo-se ao propósito do presente trabalho científico: expor singularmente as hipóteses de exceções em que a Administração Pública não licita. Foi esclarecendo a inviabilidade de competição (inexigibilidade); a vinculação do Estado em determinadas hipóteses legais (licitação dispensada); e a discricionariedade da Administração em licitar ou não a partir da conveniência e oportunidade (licitação dispensável) que esse estudo foi conduzido.

Foi de precípua relevância suceder nos princípios essenciais à temática da obrigatoriedade da Administração em licitar e nas suas exceções. Situação oportuna que se esclareceu a essência do procedimento e importantes problemáticas atuais como a conservação do meio ambiente, com a licitação sustentável de forma a se preservar as gerações futuras, conservar o meio ambiente e utilizar os recursos de forma criteriosa. Enfatizou-se a importância da ética na Administração Pública, já que a sua abstenção reflete fraudes, condutas 
amorais, pessoais e violadoras do decoro e da boa-fé. Reitera-se que todos os princípios postos foram explorados na ótica da licitação e de suas exceções.

Dessa forma, descortinada a Licitação, mencionou-se a importância desta na regulação econômica, dado que a Administração deve apresentar gastos condizentes a fim de garantir os interesses sociais, isto é, da coletividade, não havendo investimentos excessivos de modo que prejudique os cofres públicos. Foi exposto que esse procedimento é primordial na resolução de crises econômicas, visto que no seu tipo de menor preço é possível optar pela licitação mais econômica, limitando as consequências de crises financeiras.

Conclui-se que foram elaboradas ponderações das principais formas de exceção ao dever de licitar presentes no estatuto. Situações em que não é cabível a busca da melhor proposta para a Administração Pública e o mercado deixa de ser livre e competitivo. Nos mesmos moldes em que a licitação é uma garantia para o interesse público, a exceção ao dever de licitar também deve o ser.

Finalmente, o presente trabalho científico evidenciou que a Administração Pública estabelece correlações e variáveis que identificam a importância da licitação e desmitifica os procedimentos viáveis ao evidenciar os fatores contribuintes quantitativa e qualitativamente com respaldos jurídicos e éticos da licitação como contratação direta. 


\section{REFERÊNCIAS BIBLIOGRÁFICAS}

ALVARENGA, Maria Regina Scurachio Sales. Revista de Direito Administrativo Contemporâneo. Licitações e Contratos. v. 22. Ano 4. Jan. e Fev. 2016.

ARAGÃO, Alexandre dos Santos. Curso de Direito Administrativo. $2^{\mathrm{a}}$ ed. Forense. Gen, 2013.

BINENBOJM, Gustavo. Temas de Direito Administrativo e Constitucional. Ed. São Paulo: Renovar, 2008.

. Uma Teoria do Direito Administrativo. Ed. São Paulo: Renovar, 2006.

CAETANO, Marcello. Manual de Direito Administrativo. v. 1, 10 a ed. Livraria Almedina Coimbra, 1984. 1983.

. Manual de Direito Administrativo. v. 2, 9 ${ }^{\mathrm{a}}$ ed. Livraria Medina Coimbra,

Princípios Fundamentais do Direito Administrativo. Livraria Almedina Coimbra, 1996.

CARVALHO FILHO, José dos Santos. Manual de Direito Administrativo. 30 ed. Atlas, 2016.

CARVALHO, Matheus. Manual de Direito Administrativo. $2^{\mathrm{a}}$ Ed. Juspodivm, 2015 .

CUNHA JÚNIOR, Dirley da. Curso de Direito Administrativo. $14^{\mathrm{a}}$ ed. Juspodivm, 2015.

DALLARI, Dalmo de Abreu. Elementos de Teoria Geral do Estado. 32 ed. Saraiva, 2013.

DANTAS, Marilson. UnB lança sistema de governança para ajudar setor público a gerir gastos. Disponível em: $<\mathrm{http}: / /$ www.unbciencia.unb.br/humanidades/88-ciencias-contabeis/511-unb- 
lanca-sistema-de-governanca-para-ajudar-setor-publico-a-gerir-gastos> . Acessado em 21 de Outubro de 2016

DI PIETRO, Maria Silvia Zanela. Direito Administrativo. $27^{\mathrm{a}}$ ed. São Paulo. Atlas, 2014.

FANTTI, Bruna. Quase metade dos contratos da Concremat foi emergencial. Disponível em: < http://odia.ig.com.br/rio-de-janeiro/2016-04-25/quase-metadedos-contratos-da-concremat-foi-emergencial.html >. Acessada em 18 de Outubro de 2016

FERRAZ, Luciano. Função Regulatória da Licitação. Revista Eletrônica de Direito Administrativo Econômico (REDAE), Salvador, Instituto Brasileiro de Direito Público, $\mathrm{n}^{\circ}$. 21, fevereiro/março/abril, 2010. Disponível na internet: < http://www.direitodoestado.com/revista/REDAE-21-FEVEREIRO-LUCIANOFERRAZ.pdf>. Acesso em 18 de Outubro de 2016.

FIGUEIREDO, Lúcia Valle. Curso de Direito Administrativo. 9a ed. São Paulo, Malheiros, 2008.

FRIAS, Osmar Pedrosa de. Contratação direta de advogado pela Administração Pública. Disponível em: < http://mpc.ms.gov.br/uploads/upload/1321895469_ARTIGO_Osmar_PDF.pdf >. Acessada em 18 de Outubro de 2014

GARCIA, Emerson. A Improbidade Administrativa e Sua Sistematização. Disponível em < http://www.femperj.org.br/pesquisas/artigos.php >. Acessada em 20 de outubro de 2016

GARCIA, Fábio Amaral. Licitações \& contratos administrativos. $3^{\mathrm{a}}$ ed. Rio de Janeiro, Lumen juris, 2010.

GRAU, Eros Roberto. Inexigibilidade de Licitação: Serviços TécnicoProfissionais Especializados - Notória Especialização. RDP, 1999.

JUSTEN FILHO, Marçal. Comentários à lei de licitações e contratos administrativos. 9a ed. Dialética, 2002. 
KNOPLOCK, Gustavo Mello. Manual de Direito Administrativo. $9^{\mathrm{a}}$ ed. Método, 2015.

MATTOS, Mauro Roberto Gomes de. O Contrato Administrativo. $2^{\mathrm{a}}$ ed. América Jurídica, 2002.

MEDAUAR, Odete. Direito Administrativo Moderno. $9^{\mathrm{a}}$ ed. Revista dos Tribunais, 2005.

MEIRELLES, Hely Lopes. Direito Administrativo Brasileiro. 42a ed. Malheiros, 2016.

MELLO, Celso Antônio Bandeira. Curso de Direito Administrativo. $29^{\mathrm{a}}$ ed. Malheiros, 2012.

MONTEBELO, Mariana. Roteiro de Direito Administrativo. Disponível em: < https://www.passeidireto.com/arquivo/987119/roteiro-adm---marianamontebelo/9 > . Acessada em 18 de Outubro de 2015

MOREIRA NETO, Diogo Figueiredo. Curso de Direito Administrativo. $16^{\mathrm{a}}$ ed. Gen, 2014.

- Quatro Paradigmas do Direito Administrativo Pós-Moderno. Ed. Fórum, 2008.

NIEBUHR, Joel de Menezes. Licitação Pública e Contrato Administrativo. $3^{\text {a }}$ ed. Fórum, 2013.

OLIVEIRA, Rafael Carvalho Rezende. Licitações e Contratos Administrativos. $5^{\mathrm{a}}$ ed. Método, 2015.

SANTOS, Mauro Sergio dos. Curso de Direito Administrativo. Ed. Gen., 2012.

SOUTO, Marcos Juruena Villela. Direito Administrativo Contratual. Rio de Janeiro: Lumen Juris, 2004.

. Licitações \& Constratos Administrativos. $3^{\mathrm{a}}$ ed. Esplanada, 1998. 
SOUZA, Guilherme Carvalho e. A Liberdade de Contratar para a Administração Pública: a autonomia da vontade no contrato administrativo. v. 200. Revista de Direito Administrativo, 2012.

TAFNER, Wilson Ricardo Coelho. Improbidade e Ausência de prejuízo. Disponível em: <http://www.mpsp.mp.br/portal/page/portal/cao_cidadania/Improbidade_Admini strativa/Doutrina_Improbidade/3improbeaus\%C3\%AAnciadepreju\%C3\%ADzo.htm >. Acessada em 20 de outubro de 2016

VALENTE, Manoel Adam Lacayo. Marco Legal das Licitações e Compras sustentáveis na Administração Pública. Consultoria Legislativa da Câmara dos Deputados, Brasília, DF, 2011. 